\title{
A STUDY OF KEY PLAYERS IN DEVELOPING LOW CARBON BUILDINGS/COMMUNITIES IN CANADA: A CASE STUDY IN ONTARIO
}

\author{
by \\ Christine Chow \\ Bachelor of Architectural Science, University of Ryerson 2007
}

\author{
A MRP \\ presented to Ryerson University \\ in partial fulfillment of the \\ requirements for the degree of \\ Masters of Building Science (MBSc) \\ in the Graduate Program of Building Science
}

Toronto, Ontario, Canada, 2016

(C) Christine Chow 2016 


\section{Author's Declaration for Electronic Submission of a MRP}

I hereby declare that I am the sole author of this MRP. This is a true copy of the MRP, including any required final revisions.

I authorize Ryerson University to lend this MRP to other institutions or individuals for the purpose of scholarly research.

I further authorize Ryerson University to reproduce this MRP by photocopying or by other means, in total or in part, at the request of other institutions or individuals for the purpose of scholarly research.

I understand that my MRP may be made electronically available to the public. 


\section{A Study of Key Players in Developing Low Carbon Buildings / Communities in Canada - A Case Study in Ontario}

Master of Building Science (MBSc) in the Graduate Program of Building Science, 2016 Ryerson University By: Christine Chow

\section{Abstract:}

Architects, engineers, developers, contractors, building facility managers, and relevant governmental officers are the key players in developing and managing low-carbonbuildings and communities, whose decisions and actions largely determine the level of carbon emission from them. This study is intended to investigate how these key players perform in current practices and to identify any areas for improvement. This paper presents a case study conducted in Ontario, Canada's province that can best represent the leading development industry within a developed country. A significant number of key players were surveyed through questionnaires and interviews. Key findings include: (1) Although low-carbon emission is a target for the Ontario construction industry, design considerations are still highly dependent on financial limitations and more attention is required towards technical factors and (2) knowledge, skills and tools are not sufficient to support improvements to low-carbon design and development. This paper also discusses ongoing research activities and anticipated outcomes. 


\section{Acknowledgements}

The completion of this MRP could not have been possible without the support and assistance of

Dr. Zaiyi Liao and his research work towards developing low-carbon residential communities in China. Specifically, his Study of Key Players in Developing Low-Carbon Residential

Communities in China: A Case Study in Hefei had served as the basis of this research.

In addition, many thanks to all members of Footprint who supported this research with their time and effort. Special thanks to the Principal of Footprint, Lyle Scott, for supporting my study financially.

Lastly, words cannot express my sincere gratitude towards my friends and family who kept me going at times when I wanted to give up. Special thanks to my husband, Vick Chan, for your unconditional support and sacrifices to make this possible. For our soon-to-be-born child, thank you for giving me an easy pregnancy so I could concentrate and complete this paper. 


\section{Table of Contents}

Acknowledgements 


\section{List of Figures}

Figure 1: Temperature data from four international science institutions. ............................................ 1

Figure 2: Five year average variation of global surface temperatures in 1990 ...................................... 3

Figure 3: Five year average variation of global surface temperatures in 2014 ...................................... 3

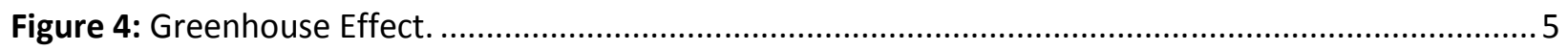

Figure 5: Global Greenhouse Gas Emissions by Gas based on global emissions from 2010..................... 5

Figure 6: Global Carbon Emissions from Fossil-Fuels 1900 - 2011 ..................................................... 7

Figure 7: $\mathrm{CO} 2$ levels during the last three glacial cycles as reconstructed from ice cores........................ 7

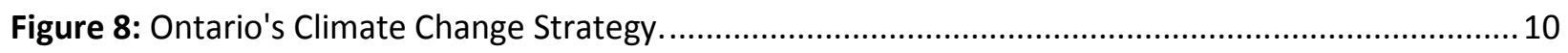

Figure 9: Greenhouse Gas Emissions across Key Sectors based on Ontario's 2013 GHG Emissions by

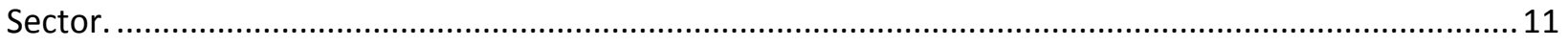

Figure 10: Greenhouse Gas Emissions by Economic Sector in Canada ................................................. 12

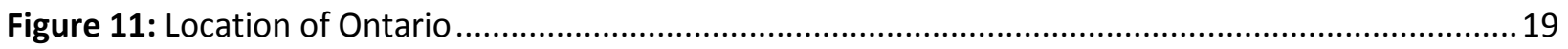

Figure 12: Conventional Construction Process in Canada................................................................... 21

Figure 13: Overall rating of fifteen influencing factors: a comparison between the actual situation with previous projects and low-carbon scenario....................................................................................... 31

Figure 14: Correlation between Quality of Environment and Marketability, Carbon Emission..................33

Figure 15: Correlation between quality of Living and Marketability, Carbon Emission ............................ 35

Figure 16: Importance of various factors in relation to marketability, carbon emission reduction,

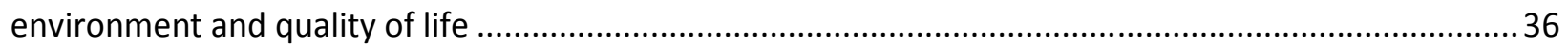

Figure 17: Relationship between the practicality of strategy / technology and level of experience......... 41

Figure 18: Relationship between the effectiveness of strategy / technology and level of experience ..... 41

Figure 19: Relationship between practicality of strategy/technology and level of experience using tools

Figure 20: Relationship between effectiveness of strategy / technology and level of skill using tools ..... 43

Figure 21: Comparison between the practicality and effectiveness of individual design strategies.........45 


\section{List of Tables}

Table 1: Key greenhouse gases emitted by human activities. Source: EPA …....................................... 6

Table 2: Ontario's Top 10 Cities and their low-carbon initiatives. ..................................................... 14

Table 3: List of influencing factors for the planning and designing of a construction development ..........23

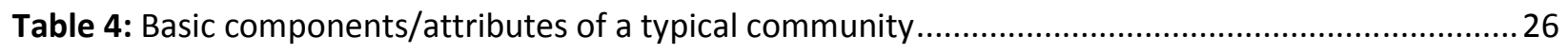

Table 5: Design strategies or technologies for low-carbon development.............................................29

Table 6: Ranking the Practicality and Effectiveness of Design Strategies / Technologies from Most to

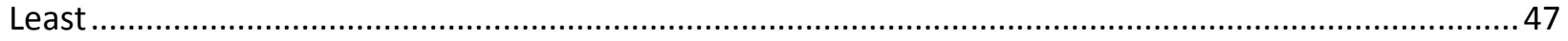




\section{Introduction}

Climate change is becoming one of the greatest threats of our time. It is defined as "any significant change in long-term weather patterns"(Government of Canada, 2015), which could be applied to any major variations in temperature, precipitation and wind patterns. Based on National Aeronautics and Space Administration (NASA)'s observation, the effects of global climate change is apparent with the shrinking of glaciers, ice on rivers and lakes breaking up earlier, shift in plant and animal ranges, and trees flowering sooner (NASA, 2015).

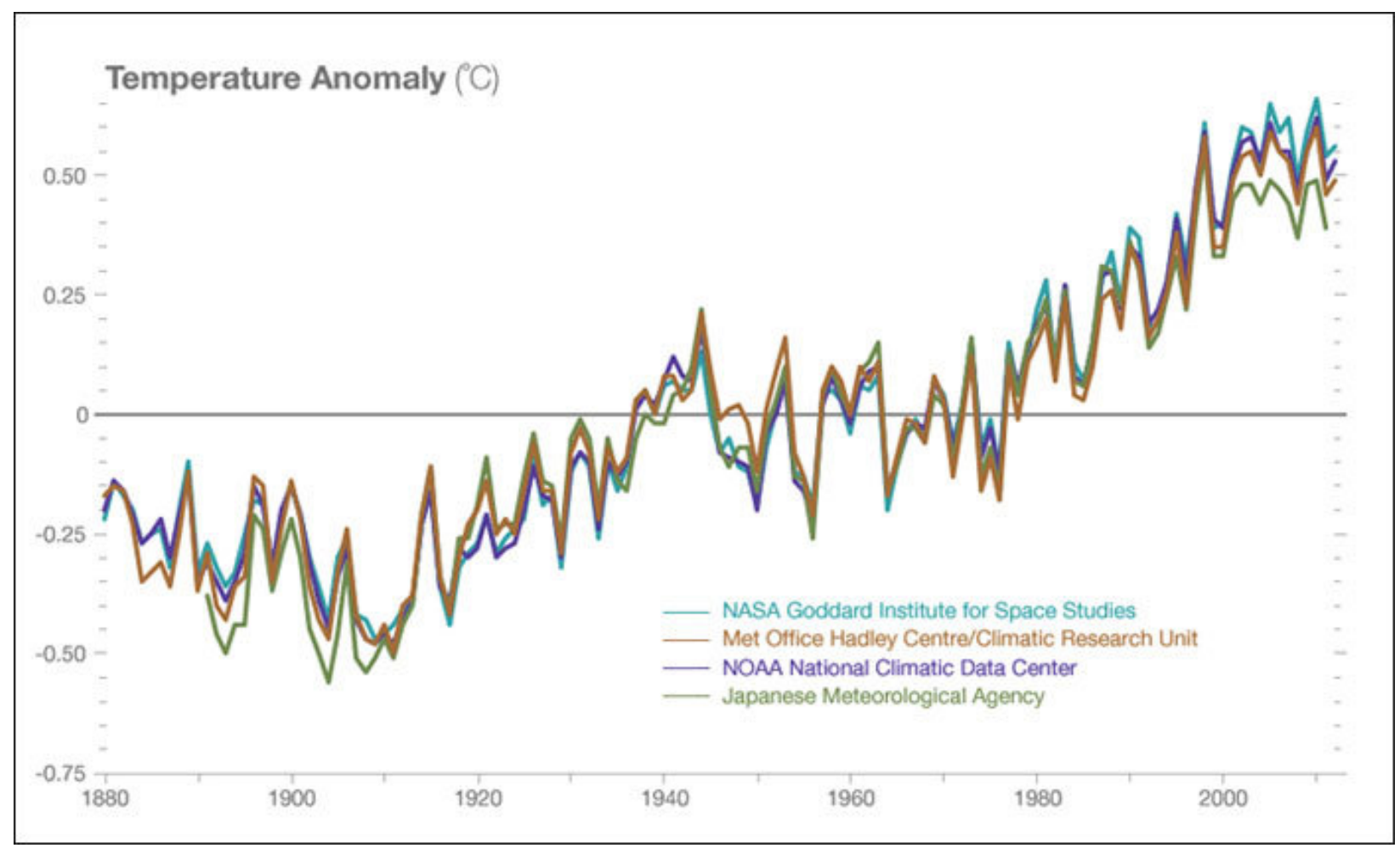

Figure 1: Temperature data from four international science institutions. All show rapid warming in the past few decades and that the last decade has been the warmest on record. Data sources: NASA's Goddard Institute for Space Studies, NOAA National Climatic Data, Met Office Hadley Centre/Climatic Research Unit and the Japanese Meteorological Agency. Credit: NASA. (NASA, 2015) 
One of the major causes of climate change is global warming, where a long-term rise in global average surface temperature is observed. Figure 1 illustrates the change in global surface temperature between 1880 and 2005; the data was collected by NASA's Goddard Institute for Space Studies, NOAA National Climatic Data, Met Office Hadley Centre/Climatic Research Unit and the Japanese Meteorological Agency. Figure 2 and Figure 3 shows the five-year average variation of global surface temperatures for 1990 and 2014. Dark blue indicates areas cooler than average and dark red indicates areas warmer than average.

The Intergovernmental Panel on Climate Change (IPCC), which includes more than 1,300 scientists from around the world, forecasts a temperature rise of $2.5^{\circ} \mathrm{F}$ to $10^{\circ} \mathrm{F}\left(1.4^{\circ} \mathrm{C}-5.5^{\circ} \mathrm{C}\right)$ over the next century (IPCC, 2014). "Warming of the climate system is unequivocal, as is now evident from observations of increases in global average air and ocean temperatures, widespread melting of snow and ice, and rising global average sea level." (IPCC, 2007) According to IPCC, the extent and effects of climate change on individual regions will vary over time, where in some cases it may produce beneficial impacts and harmful ones in others. "Taken as a whole, the range of published evidence indicates that the net damage costs of climate change are likely to be significant and to increase over time." (IPCC, 2007) 


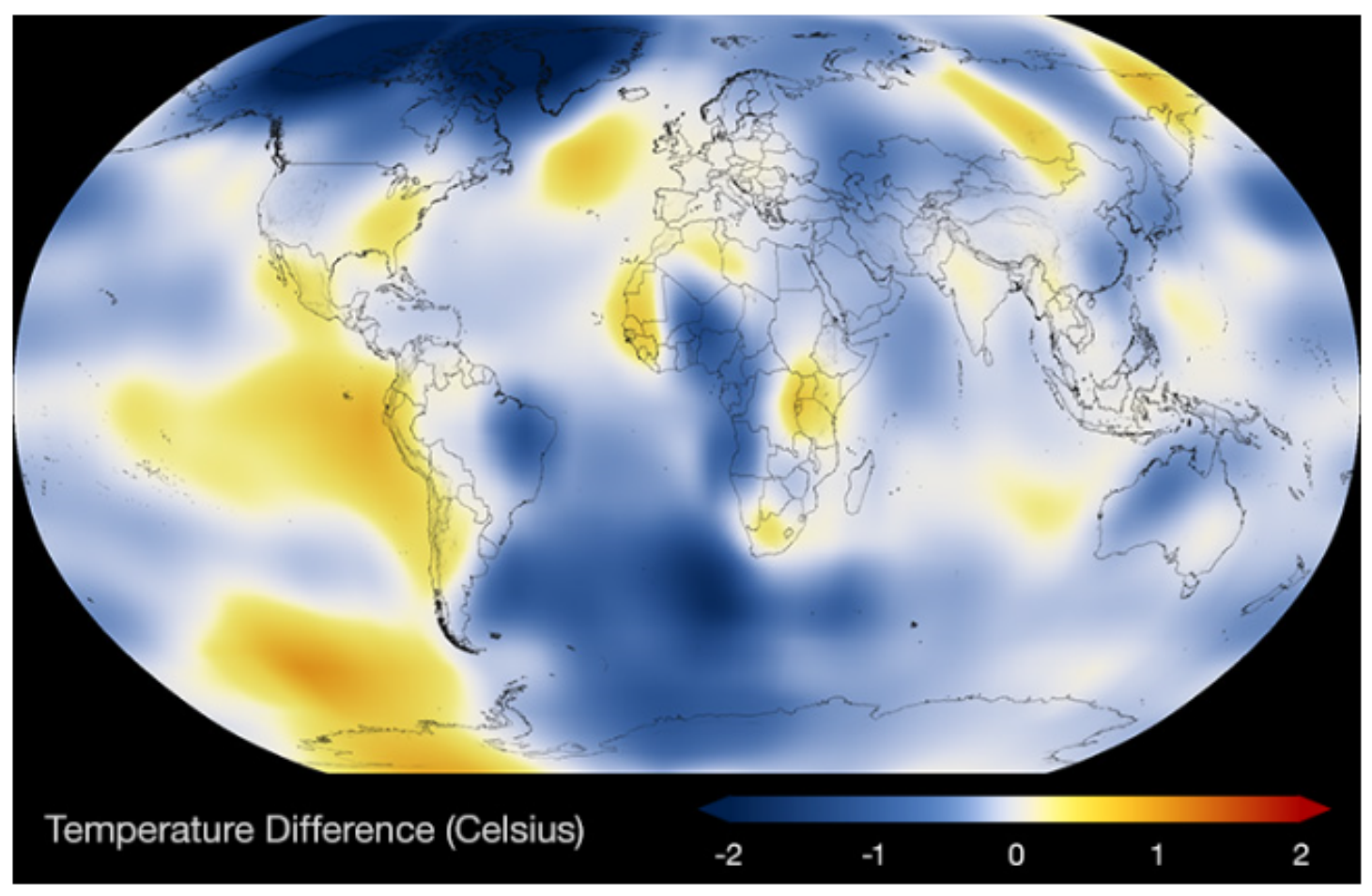

Figure 2: Five year average variation of global surface temperatures in 1990. Data Source: NASA/GISS. Credit: NASA Scientific Visualization Studio.(NASA, 2015)

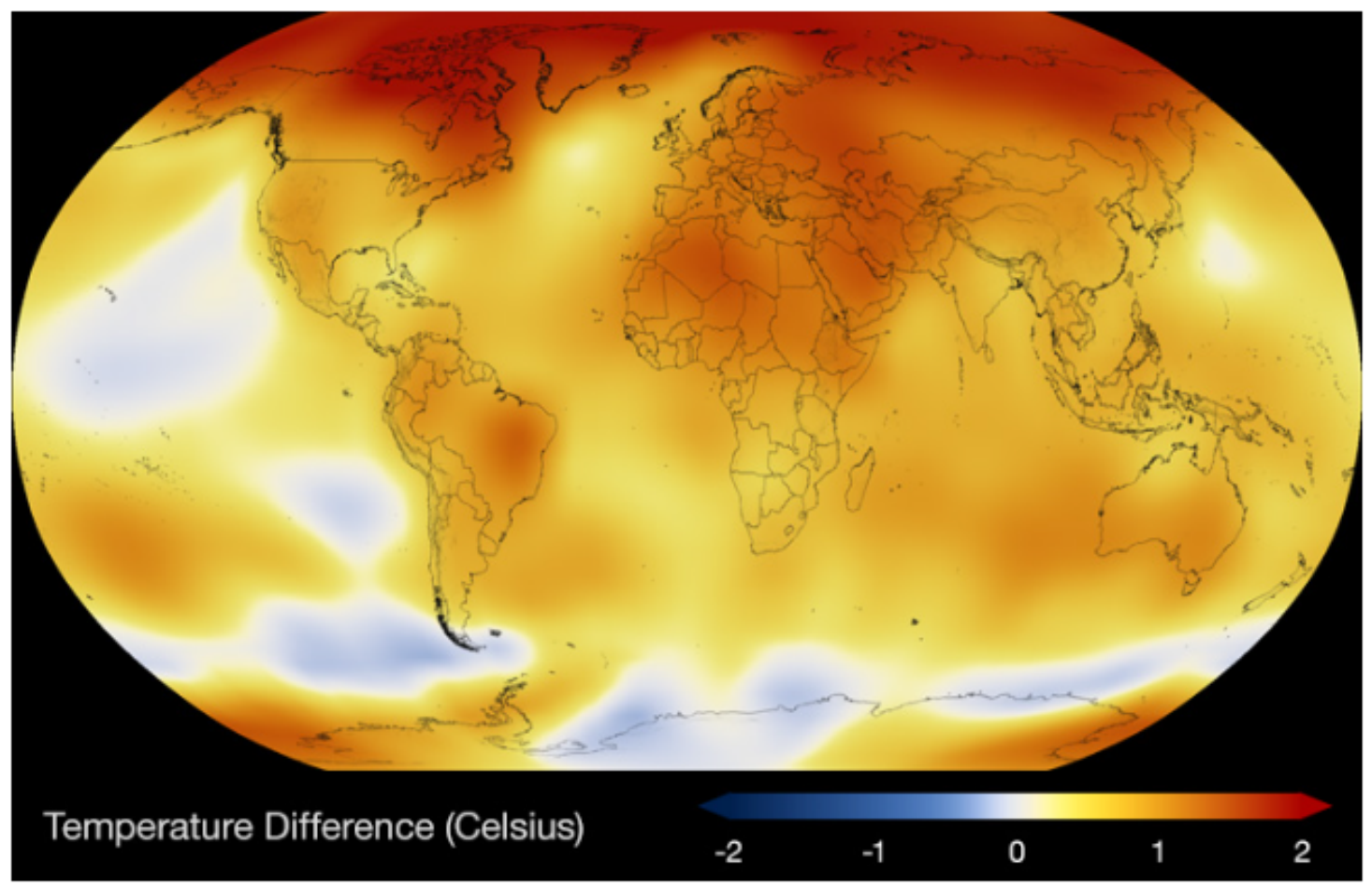

Figure 3: Five year average variation of global surface temperatures in 2014. Data Source: NASA/GISS. Credit: NASA Scientific Visualization Studio. (NASA, 2015) 
Since the Industrial Revolution in 1750, global warming has been largely attributed to human influences due to the expansion of the "greenhouse effect"(IPCC, 2007), (United States Global Change Research Program, 2009), (Oreskes, 2004); warming that results when the atmosphere traps heat radiating from Earth towards space. Ninety-seven percent or more of actively publishing climate scientists agree: Climate-warming trends over the past century are very likely due to human activities (Cook, et al., June 2013), (W. R. L. Anderegg, 2010), ( P. T. Doran \& M. K.Zimmerman, 2009). In addition, approximately 200 leading scientific organizations worldwide have issued public statements endorsing this position (OPR (Office of Planning and Research), 2011).

Based on EPA (United States Environmental Protection Agency), the "greenhouse effect" is problematic because it interferes with Earth's balance of temperature. As sunlight reaches the Earth's surface, it can do one of two things: reflect back into space or be absorbed by Earth. Absorbed energy can be released back into the atmosphere as heat, also known as infrared radiation. However, "greenhouse gases like water vapor $\left(\mathrm{H}_{2} \mathrm{O}\right)$, carbon dioxide $\left(\mathrm{CO}_{2}\right)$, and methane $\left(\mathrm{CH}_{4}\right)$ absorb energy, slowing or preventing the loss of heat to space. In this way, greenhouse gases act like a blanket, making Earth warmer than it would otherwise be." (EPA, 2015) Figure 4 outlines the principles of the atmospheric greenhouse effect, absorbing heat and warming the surface by 15 degrees Celsius (NASA, 2015). 


\section{Sunlight passes through the atmosphere and}

\section{warms the Earth's surface. This heat}

is radiated back toward space.

Most of the outgoing heat is absorbed by greenhouse gas molecules and re-emitted in all directions, warming the surface of the Earth and the lower atmosphere.

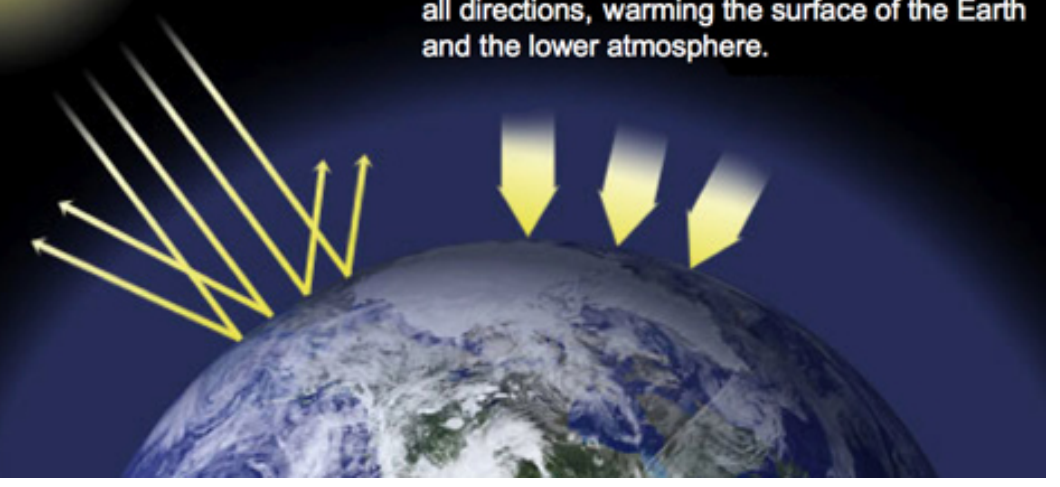

Figure 4: Greenhouse Effect. Source: NASA.

Human activities contribute to climate change as it adds greenhouse gases to the atmosphere.

Based on EPA's data, the key greenhouse gases emitted by human activities at the global scale are outlined in Table 1 below. In addition, the global greenhouse gas emissions by gas is outlined in Figure 5 based on the latest IPCC Climate Change 2014: Mitigation of Climate Change Report.

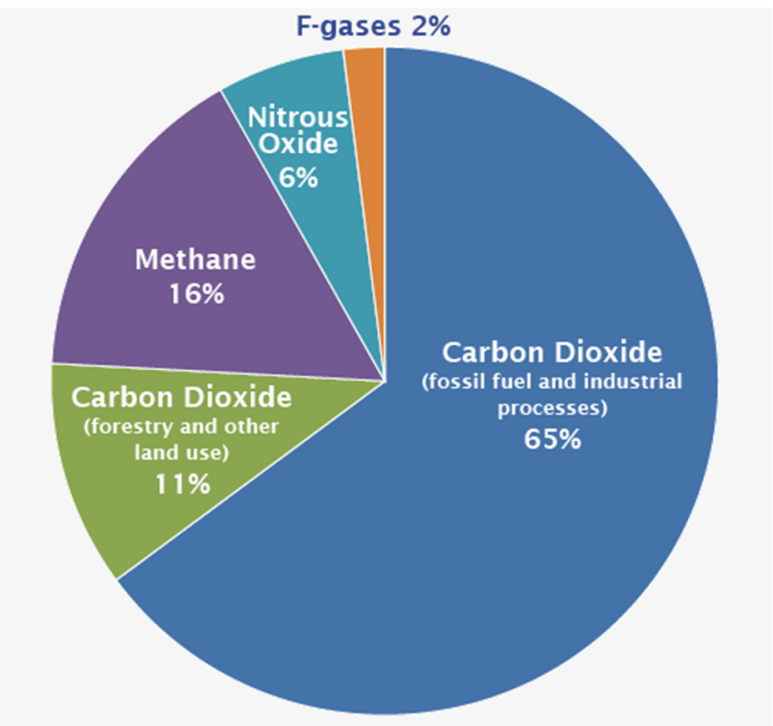

Figure 5: Global Greenhouse Gas Emissions by Gas based on global emissions from 2010.(IPCC, 2014) 
Table 1: Key greenhouse gases emitted by human activities. Source: EPA

\begin{tabular}{|c|c|}
\hline Greenhouse Gas & Human Activities \\
\hline Carbon dioxide $\left(\mathrm{CO}_{2}\right)$ & $\begin{array}{l}\text { Fossil fuel use is the primary source of } \mathrm{CO}_{2} \text {. The way in which people } \\
\text { use land is also an important source of } \mathrm{CO}_{2} \text {, especially when it } \\
\text { involves deforestation. } \mathrm{CO} 2 \text { can also be emitted from direct human- } \\
\text { induced impacts on forestry and other land use, such as through } \\
\text { deforestation, land clearing for agriculture, and degradation of soils. } \\
\text { Likewise, land can also remove } \mathrm{CO}_{2} \text { from the atmosphere through } \\
\text { reforestation, improvement of soils, and other activities. }\end{array}$ \\
\hline Methane $\left(\mathrm{CH}_{4}\right)$ & $\begin{array}{l}\text { Agricultural activities, waste management, energy use, and biomass } \\
\text { burning all contribute to } \mathrm{CH} 4 \text { emissions. }\end{array}$ \\
\hline Nitrous oxide( $\left.\mathrm{N}_{2} \mathrm{O}\right)$ & $\begin{array}{l}\text { Agricultural activities, such as fertilizer use, are the primary source of } \\
\mathrm{N}_{2} \mathrm{O} \text { emissions. Biomass burning also generates } \mathrm{N}_{2} \mathrm{O} \text {. }\end{array}$ \\
\hline $\begin{array}{l}\text { Fluorinated gases }(\mathrm{F}- \\
\text { gases) }\end{array}$ & $\begin{array}{l}\text { Industrial processes, refrigeration, and the use of a variety of } \\
\text { consumer products contribute to emissions of F-gases, which include } \\
\text { hydrofluorocarbons (HFCs), perfluorocarbons (PFCs), and sulfur } \\
\text { hexafluoride (SF6). }\end{array}$ \\
\hline
\end{tabular}

The figures above indicate that global carbon emission is the most concerning of all the different greenhouse gases. Focusing on carbon emissions alone, global carbon emissions from fossil fuels have significantly increased since 1900 (refer to Figure 6). Since 1970, $\mathrm{CO}_{2}$ emissions have increased by about $90 \%$ (refer to Figure 7), with emissions from fossil fuel combustion and industrial processes contributing about $78 \%$ of the total greenhouse gas emission. Agriculture, deforestation, and other land use changes are the second-largest contributors. (IPCC, 2014), (NASA, 2015) 


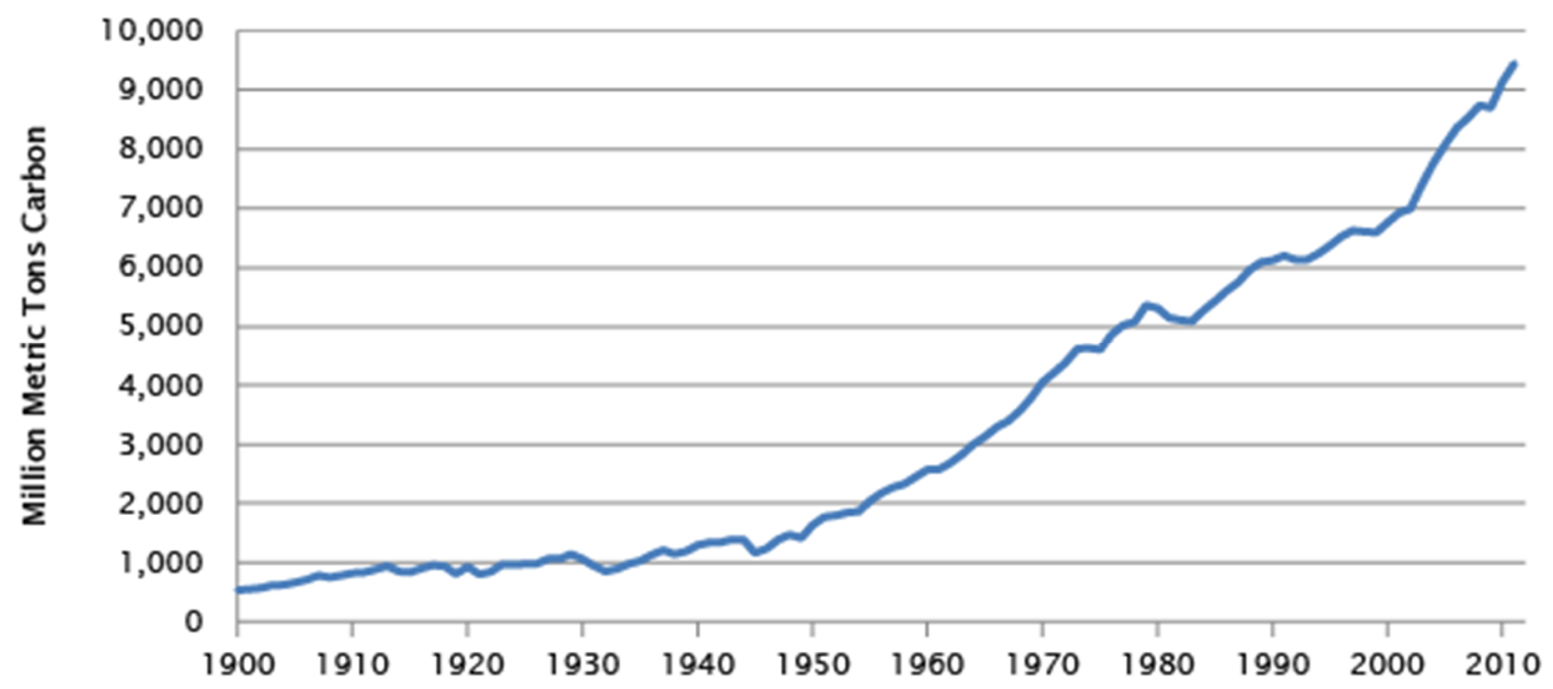

Figure 6: Global Carbon Emissions from Fossil-Fuels 1900 - 2011. Source:(Boden, Marland, \& Andres, 2015)

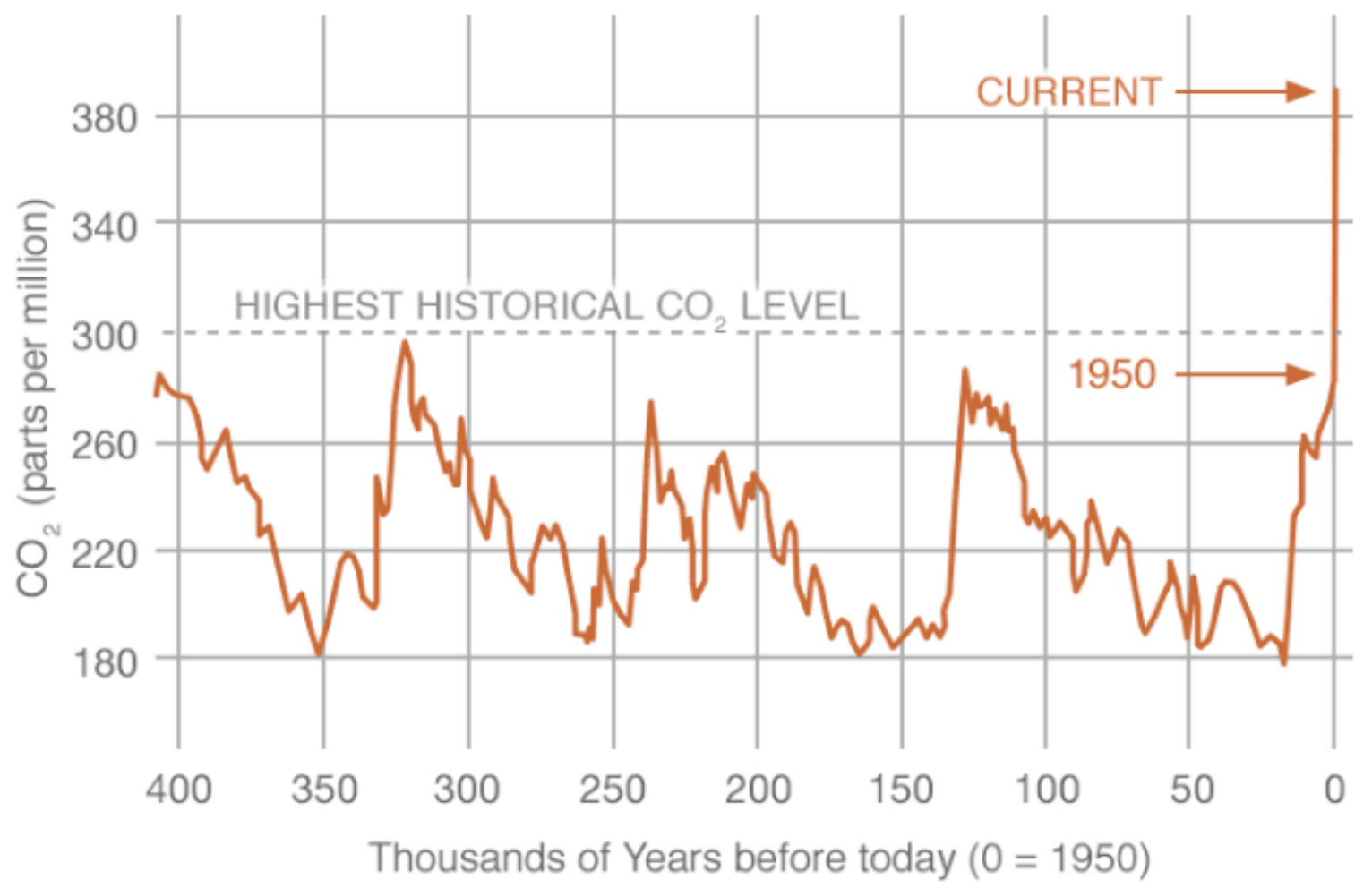

Figure 7: $\mathrm{CO} 2$ levels during the last three glacial cycles as reconstructed from ice cores. Data source: Reconstruction from ice cores. Credit: NOAA(NASA, 2015) 
As a result, there is a global need to take action against climate change. The United Nations Framework Convention on Climate Change (UNFCCC) was established in 1992, acknowledging the existence of human-induced climate change and giving industrialized countries the major part of the responsibility for reducing it. UNFCCC's objective was to stabilize atmospheric greenhouse gas concentrations at a level that would prevent any further dangerous human interference with the climate system. After 5 years of negotiations, the Kyoto Protocol was adopted, which for the first time set quantified greenhouse gas reduction commitments for developed countries between 2009 and 2012. During years 2007 - 2012, various negotiations and conferences were held to develop the next international agreement following the Kyoto Protocol. As a result, the Doha Conference officially launched the second commitment period of the Kyoto Protocol (2013 and 2020).

Recently, the 21st Conference of the Parties to the UNFCCC (COP21) took place from November 30 - December 11, 2015; focusing on the establishment of a new international agreement on climate change, applicable to all, to keep global warming below 2 degree Celsius. A total of 186 countries were participating in the COP21, and Canada intends to be a climate leader in this movement. The Government of Canada's new approach to global climate action is built on the following:

- Fact-based decision making and robust science, reflecting the latest findings from the Intergovernmental Panel on Climate Change.

- Recognition of the necessity of transitioning to a low-carbon, climate resilient economy. 
- Strong collaboration with provinces and territories, and non-state actors to take concrete climate action.

- Support for climate resilient development and adaptation in countries that need it.

Canada has high hopes towards the results from the negotiations at the COP21, including the establishment of an ambitions and effective global agreement, keeping emissions in check, enhancing accountability and transparency, supporting climate change adaptation, promoting cost effective climate policies, investing towards a low-carbon future for all, sustaining momentum and progress, and seeking early wins in the pre-2020 period. (Government of Canada, 2015)

In support of this movement, "Government of Canada will provide national leadership and join with the provinces and territories to take action on climate change, put a price on carbon, and reduce carbon pollution" (Government of Canada, 2015). This includes ensuring that the provinces and territories have targeted federal funding and flexibility to design their own carbon pricing policies. In addition, the Government of Canada will protect communities and grow its economy by making significant new investments in green infrastructure and clean technologies such as the following:

- Endow a \$2 billion Low Carbon Economy Trust to fund projects that reduce carbon.

- Fulfill our G20 commitment and phase out subsidies for the fossil fuel industry.

- Work with the Provinces and Territories to develop a Canadian Energy Strategy to protect Canada's energy security, encourage energy conservation, and bring cleaner renewable energy into the electricity grid. 
Ontario, the most populated province in Canada (Statistics Canda, 2015), has demonstrated leadership to fighting climate change, committing to "protect the environment, build a lowcarbon, high-productivity economy and ensure strong communities for the future" (Ontario, 2015) .To date, Ontario has already taken bold measures such as ending coal-fired power, improving the province's transit network, and announcing a cap and trade program to limit greenhouse gas pollution and fight climate change. In addition, Ontario is aiming to reduce greenhouse gas emissions by $80 \%$ below 1990 levels by 2050 . This vision will create communities that are climate-resilient, complete and compact (Ontario, 2015). Ontario's Climate Change Strategy summarized in Figure 8.

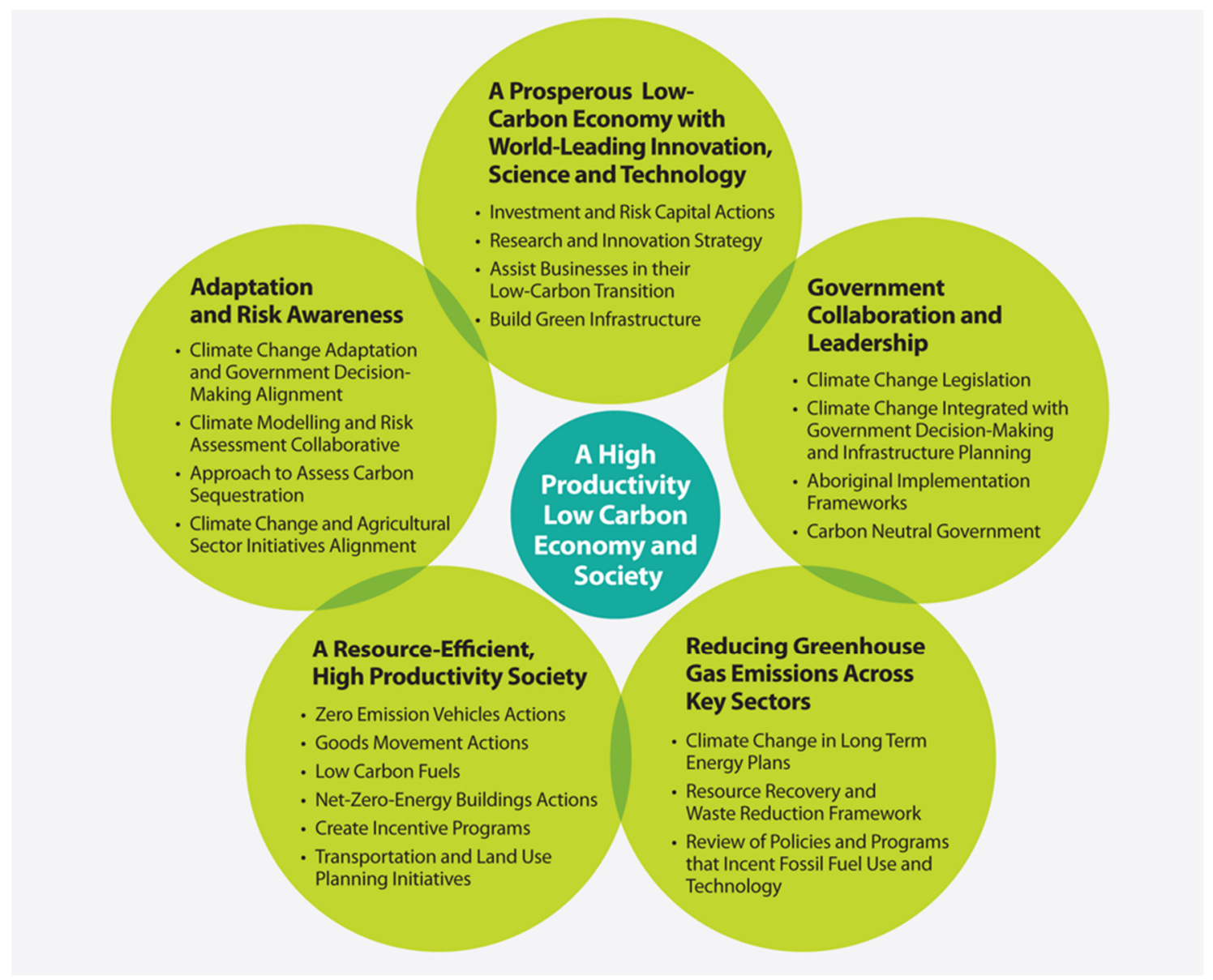

Figure 8: Ontario's Climate Change Strategy. Source: (Ontario, 2015) 
Focusing on the "Reducing greenhouse gas emissions across sectors", Figure 9 outlines the greenhouse gas emissions across key sectors in Ontario. The greenhouse gas emission distribution across different sectors in Ontario is very different than the percentage distribution in Canada (refer to Figure 10). Most of the greenhouse gas emissions in Ontario come from transportation, industry and buildings sectors, where majority of the greenhouse gas emissions in Canada comes from oil and gas, transportation, buildings, and electricity. The discrepancies between Figure 9 and Figure 10 may be due to population concentration and the amount of factories located in Ontario versus Canada as a whole. For the intents and purposes of this study, we will focus on the emissions in Ontario.

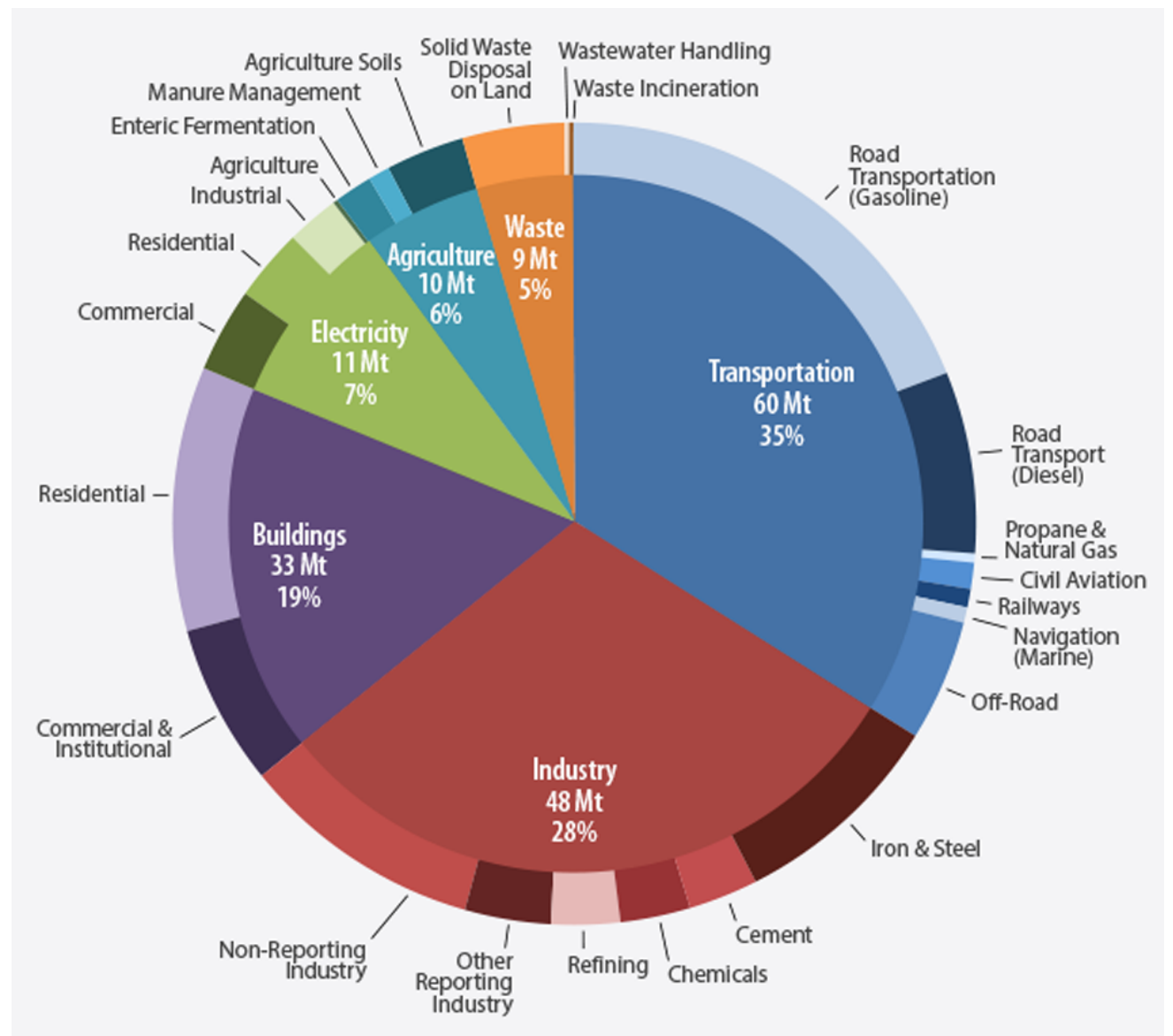

Figure 9: Greenhouse Gas Emissions across Key Sectors based on Ontario's 2013 GHG Emissions by Sector. 


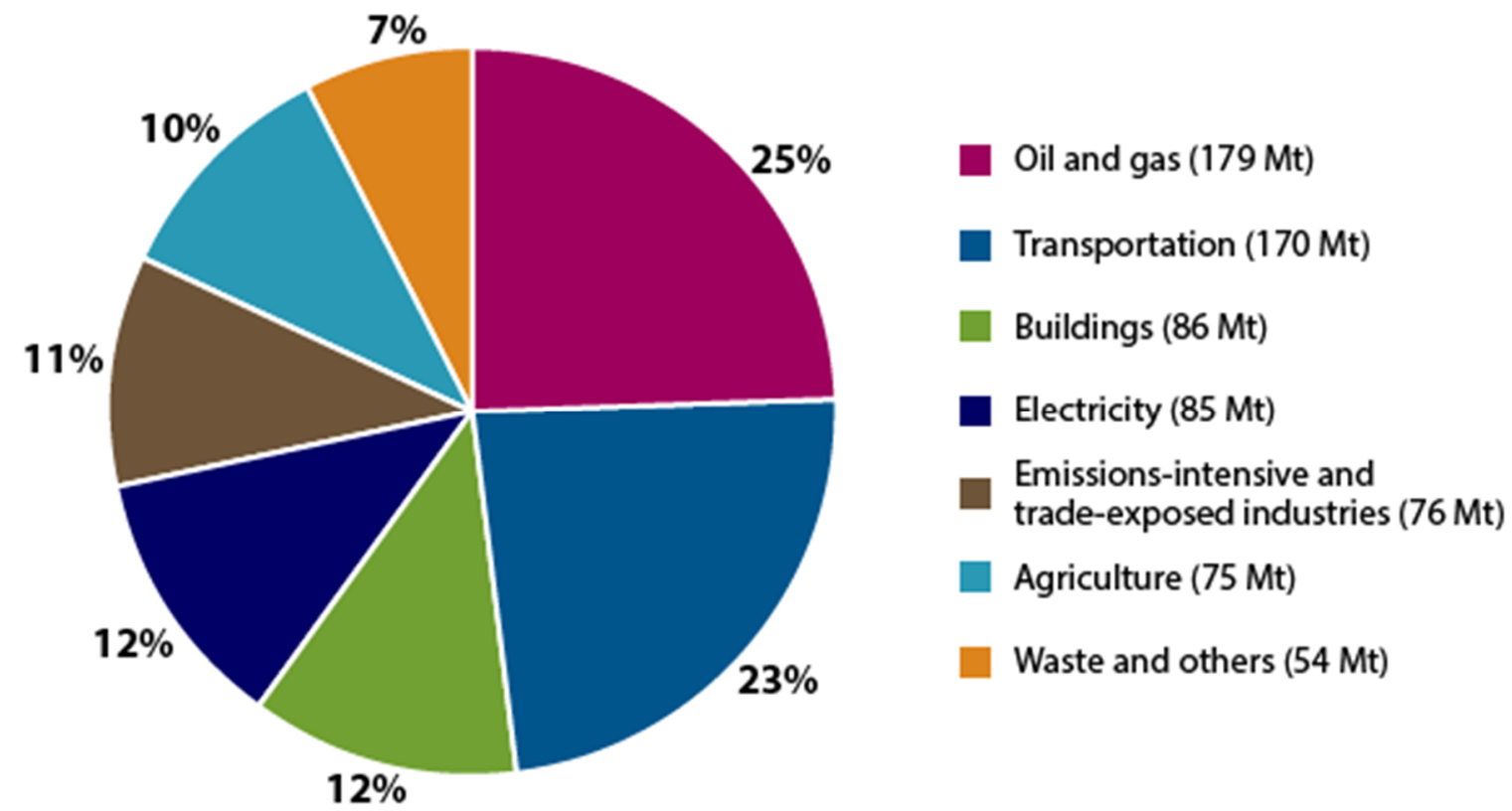

Figure 10: Greenhouse Gas Emissions by Economic Sector in Canada <http://www.ec.gc.ca/indicateurs-indicators/default.asp?lang=en\&n=F60DB708-1>

To target the three largest carbon emitting sectors, Ontario has put forth the following sectorspecific actions and technology innovations to achieve greenhouse gas reduction targets. All information below are extracted from Ontario's Climate Change Strategy published in December 13, 2015.

Transportation: The role of public transit plays a very important role in getting people out of passenger car trips which can account for over 10 million trips per day. Based on existing land use patterns and the location of suburban employment centers, although transit alone will not serve the majority of Ontarians' day-to-day needs, it will help alleviate congestion and offer a low-carbon transportation alternative. New communities will also be built alongside transit with sustainable densities. To further reduce 
greenhouse gas emission, Ontario will focus on helping households shift to affordable and viable ultra-low and zero-emission vehicles (i.e. hybrid and electric vehicles).

Industry: Emissions from the industry sector has dropped by 21 percent between 1990 and 2012 which is mainly due to the implementation of energy efficiency measures, contraction and shifts in the manufacturing sector.

Buildings: The building sector represents about $19 \%$ of the province's total greenhouse gas emissions. This number rises to about $24 \%$ when electricity (used by equipment and appliances in buildings) is taken into account. Measures such as conservation and retrofits have led to significant improvement in emissions intensity in the buildings sector, yet emissions caused by buildings overall are still rising due to population and economic growth, and the associated increase in buildings and floor space.

Based on a study conducted by Pacala and Scolow, improvements in building efficiency is one of seven "stabilization wedges" that could help offset global increases in carbon emissions over the next 50 years. As a result, the buildings sector must take an active role in developing strategies to achieve the greenhouse gas emission reduction goals of $37 \%$ by 2030 (Ontario, 2015). This goal is influenced by the 2030 Challenge developed by Architecture 2030, where rigorous targets are established for reducing carbon emissions from new buildings. Currently, the goal is to design buildings that use 60 percent less annual energy than average for that building type (Architecture 2030, 2015). Ontario envisions by 2030, a framework would be established to minimize energy use and to use renewable energy in buildings. This includes "putting in place buildings-science expertise, production capacity for buildings materials and 
the technologies and workforce to maintain and build near-net-zero buildings." (Ontario, 2015) The target would be creating residential and commercial buildings that uses renewable technology to produce as much energy as it consumes. Ontario will "support net-zero buildings across the province through updates to Ontario's Building Code, incentive programs, removal of regulatory barriers, and encouraging the transition to lower carbon fuels and to building materials that store carbon." (Ontario, 2015)

To further encourage this vision, various cities in Ontario are mandating buildings to comply with various sustainable standards or provide other incentives to encourage low-carbon development. Below is a list of Ontario's top 10 major cities (based on population) and their respective low-carbon initiatives.

Table 2: Ontario's Top 10 Cities and their low-carbon initiatives.

\section{Major Cities in Ontario Low-Carbon Initiatives}

\begin{tabular}{|c|c|}
\hline Toronto & $\begin{array}{l}\text { All new construction in Toronto must comply with the Toronto } \\
\text { Green Standard (TGS). The TGS integrates environmental } \\
\text { performance requirements to improve our air and water quality, } \\
\text { reduce greenhouse gas emissions, enhance urban ecology and } \\
\text { reduce solid waste to landfill. (Toronto, 2015) }\end{array}$ \\
\hline Ottawa & $\begin{array}{l}\text { All new municipal buildings will have to comply with the Green } \\
\text { Building Policy (Vaughan, 2015), which includes: } \\
\text { - All newly constructed buildings with a footprint greater } \\
\text { than } 500 \text { square metres (5,400 square feet) must be } \\
\text { designed, delivered and certified by the Canada Green } \\
\text { Building Council (CaGBC) as being LEEDTM - Canada } \\
\text { "Certified" at minimum. }\end{array}$ \\
\hline
\end{tabular}


- All newly constructed buildings will incorporate energy efficient features into the building design to meet the standards required by the Commercial Building Incentive Program (CBIP).

- The City encourages the application of sustainable design principles during retrofit and renovation projects of its current structures where practical.

- Historic structures shall be exempt from the requirements of this policy. However, wherever practical, best efforts should be made to incorporate as many of the green building requirements and credits from the LEED ${ }^{T M}$ Green Building Rating System as possible, without compromising the historical integrity of the structure.
Mississauga
A Green Development Strategy is on course for full
implementation over the next five years, including the following requirements (Mississauga, 2015):
- Private new developments will have to include best sustainable technologies and practices as part of their proposals
- All Municipal Buildings will comply with "City of Mississauga Green Building Standard for Municipal Buildings" which aspires to LEED Silver Certification
Brampton In 2003, Brampton adopted the Development Design Guidelines (DDGs) which provides the minimum design standard for new communities. Part 8 of the document focuses on Sustainable Community Development (Brampton, 2015). No building scale initiatives are currently present.
Hamilton Sustainable building and sustainable land development practices located within the LEEDING the Way Community Improvement 


\begin{tabular}{|c|c|}
\hline & $\begin{array}{l}\text { Project Area could apply for a grant from the City of Hamilton to } \\
\text { share the incremental construction cost, consultation, and energy } \\
\text { modeling and certification fees with the applicant to achieve LEED } \\
\text { certification (The City of Hamilton, 2013). }\end{array}$ \\
\hline London & None \\
\hline Markham & None (Markham, 2014) \\
\hline Vaughan & $\begin{array}{l}\text { Buildings constructed in the City of Vaughan are encouraged to be } \\
\text { certified under LEED (Leadership in Energy and Environmental } \\
\text { Design) rating system, an internationally accepted benchmark for } \\
\text { the design, construction and operation of high-performance green } \\
\text { buildings. (Vaughan, 2015) }\end{array}$ \\
\hline Kitchener & $\begin{array}{l}\text { Starting in April 2005, all new Regional buildings larger than } 500 \\
\text { square meters of occupied space would be constructed to the } \\
\text { Silver level defined by the internationally accepted Leadership in } \\
\text { Energy and Environmental Design (LEED }{ }^{\circledR} \text { ) standard (Region of } \\
\text { Waterloo, 2010). }\end{array}$ \\
\hline Windsor & $\begin{array}{l}\text { The City of Windsor is in the process of preparing a new Site Plan } \\
\text { Design Manual that will set out standards that require more } \\
\text { sustainable development practices related to site design and the } \\
\text { building exterior (City of Windsor, 2015). Examples of measures } \\
\text { being considered include: } \\
\text { - Solar orientation of buildings } \\
\text { - Transit and pedestrian friendly building orientation } \\
\text { - Best management practices for storm water control } \\
\text { - Shade trees } \\
\text { - Window canopies } \\
\text { - Reflective roofing materials, etc. }\end{array}$ \\
\hline
\end{tabular}


The three primary approaches to designing low-carbon buildings could be summarized as follow (Ochsendorf, 2012):

1. Improving design strategies

2. Improving the efficiency of technologies and systems

3. Using off-site renewable energy, such as off-shore wind energy

One of the biggest challenge towards low-carbon building / community development is that key players are involved too late in the design process, specifically the engineers. "Many key decisions, such as building orientation, glazing ratio (i.e., area of glass/area of opaque wall), and the overall form of the building are made in the earliest design stages. Once these critical decisions have been made, engineers can attempt to optimize a poor design, but it is difficult at that point to achieve a low-carbon design (Ochsendorf, 2012)." Other challenges include the lack of professionals with necessary skills and knowledge as most engineering schools do not directly address the design and operation of buildings. To effectively design low-carbon buildings, one needs to be trained in building science and sustainable design which involves aspects of mechanical engineering, civil engineer, and architecture. When designing a lowcarbon community, knowledge in landscaping and planning will also be required.

Based on the extensive literature study identified above, a deep interest on the current status of the Ontario construction industry towards low-carbon development was developed. After understanding the work currently conducted by Dr. Zaiyi Liao in Hefei, China, titled A Study of Key Players in Developing Low-Carbon Residential Communities in China: A Case Study in Hefei, it appears a similar study could be conducted in Ontario, Canada that could help evaluate the 
construction industry's readiness towards low-carbon development. The study conducted by Dr. Zaiyi Liao has great success, with over 545 responding individuals which represented $10 \%$ of the total population of relevant professionals working in the city of Hefei (Liao, 2013). The significance of Liao's work extends more than the city itself, but a representation of how a middle-sized $2^{\text {nd }}$-tier city in China have been developed over the last three decades. Once the work is complete in Ontario, Canada, a developed country; a comparative study may be of interest to understand the differences between a developing country and a developed country. To allow for a successful comparison, only minor modifications were made to the methodology of the research to make it sensitive to the location, and identical equations were used for evaluating the collected data.

This study is aimed to investigate the current practice of key players in Ontario, including property project planners, architects, engineers, contractors and building managers and to identify the areas of knowledge shortage, skill and tool deficiency towards low-carbon building and community development. A simple question that this study is intended to answer is: "is the construction industry ready for or moving towards low-carbon building/ community development? And, if not, what is missing?" The research goal is to be achieved through a series of research activities, including:

(1) Survey the current practice of key players through questionnaires and interviews.

(2) Survey behavior of occupants of typical residential and commercial communities.

(3) Assess the indoor and outdoor environment in selected residential and commercial communities.

(4) Audit energy performance of typical residential and commercial units. 
(5) Study selected residential and commercial communities by simulation.

(6) Employ the research outcome in practice.

This report presents the results of questionnaire survey conducted in Ontario, Canada. With a population of 13.7 million, Ontario is the most populated province in Canada, accounting for approximately 38\% of the country's total population (Statistics Canda, 2015). Figure 11 shows the location of Ontario. Within the province, major cities are well connected by highways and a high-speed train network. The influence of the construction industry in this province radiates to the entire country. It is believed the findings from this survey will be representative of the situation in other major provinces in the foreseeable future. The results of studies in other provinces will be published separately.

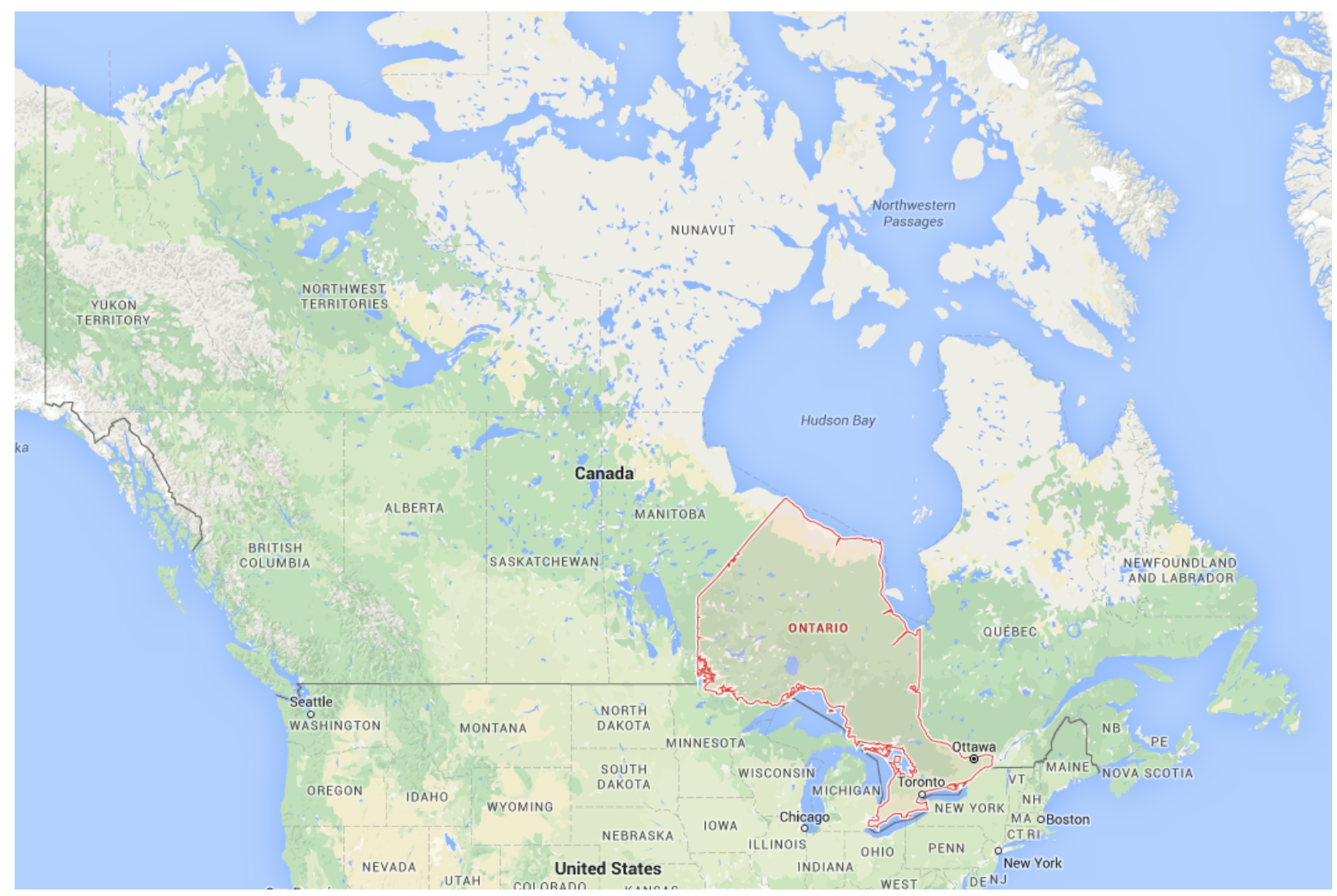

Figure 11: Location of Ontario (https://www.google.ca/maps/place/Ontario/) 


\section{Methodology}

Figure 12 illustrates the conventional process (also known as the traditional approach) in building and community development in Canada. In this process, design work is generally separated from construction, where consultants are appointed for design and cost control, and the contractor is responsible for carrying out the works (CRC Construction Innovation, 2006). The other typical procurement process is known as the Design Construction or Design Build, where the contractor accepts responsibility for some or all of the design. The contractor is involved during the design stages which allows for close integration of design and construction methods and the relative freedom of the contractor to use their purchasing power and market knowledge most effectively (CRC Construction Innovation, 2006). Recently, the industry is adopting an integrative design process (IDP) where all key players identified below work collaboratively from conception to completion. The IDP is most favorable when designing lowcarbon buildings as it involves a holistic approach to high performance building design construction. "It relies upon every member of the project team to sharing a vision of sustainability, and work collaboratively to implement sustainability goals. This process enables the team to optimize systems, reduce operating and maintenance costs and minimize the need for incremental capital (Government of Canada, 2015)." Other procurement processes used in the industry include Management Procurement, and Public-Private-Partnership (P3).

Regardless the process, building and community development projects still follow similar constructional phases, which can be simplified into four major phases: pre-design, design, 
construction and operation. Key players in these phases (if following the conventional process) are as follow:

- Pre-design: developer (or owner), project planner

- Design: developer (or owner), architect and engineer

- Construction: developer (or owner), architect, engineer, contractor, commissioning agent

- Marketing (may overlap with Construction): developer, marketing agent

- Operation (occupancy): building operator, owner

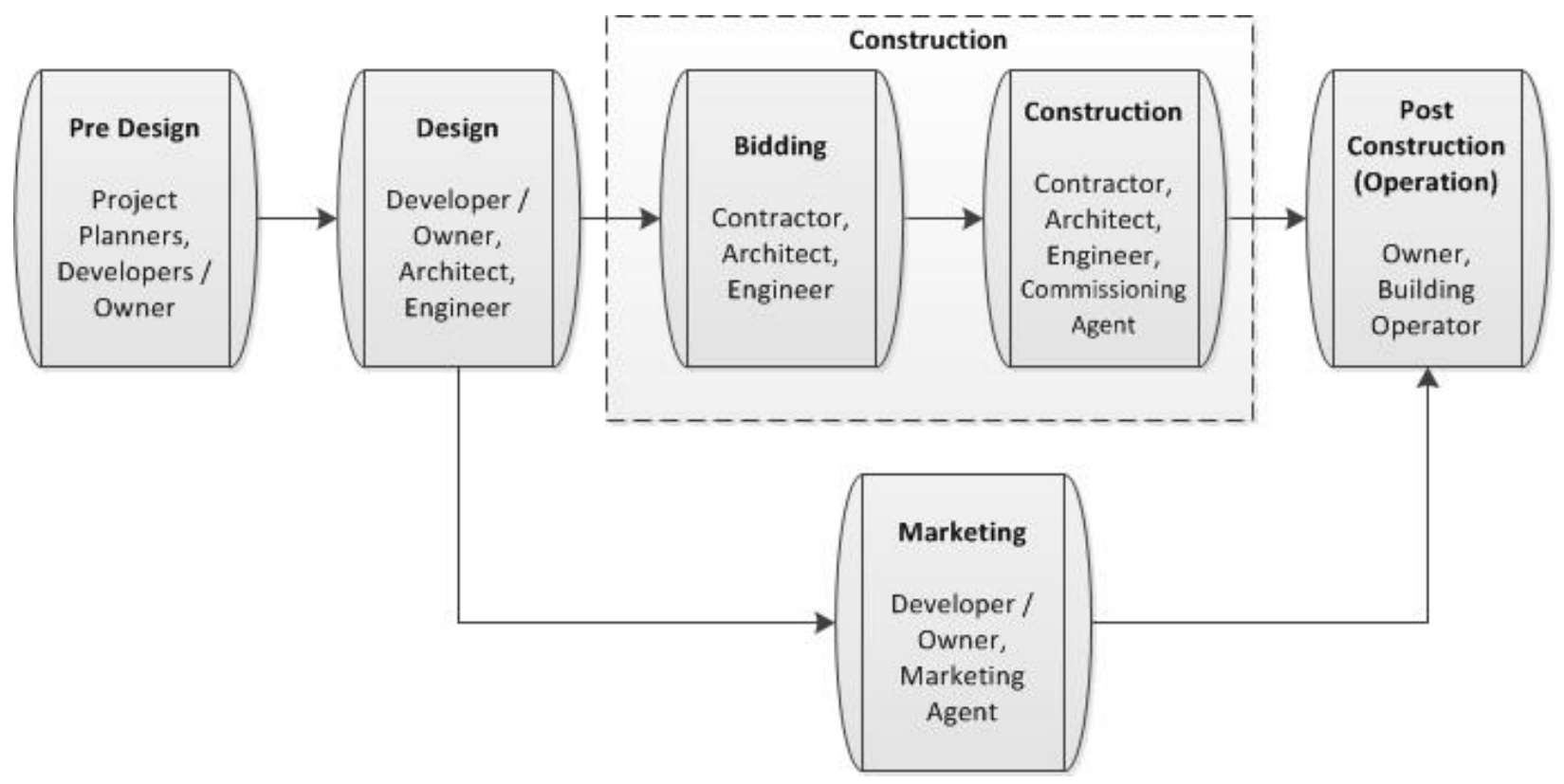

Figure 12: Conventional Construction Process in Canada. Source: (Green Building Education Services, 2015)

The decisions made by these key players determine the performance of the resulting development. To understand the construction industry's response towards developing lowcarbon buildings/ communities, it is essential to understand how familiar these key players are with the fundamentals and best practices of low-carbon design. The study is based on a questionnaire survey that is organized into four phases designed to find the following: 
(1) What are the influencing factors for the planning and designing of residential and commercial building development?

(2) How do the components of a typical residential and commercial community affect carbon emission?

(3) What new technologies and knowledge can be employed in low-carbon building/ community development?

(4) Does the current construction industry allow for appropriate adaptation and employment of low-carbon technologies and knowledge?

To ensure that the questionnaire can be easily understood and answered with accuracy, the questions are designed with common terms shared by the targeted key players and formulated using a rating scale of five points. These questions are organized into three groups.

Group 1: Within a range of 1 to 5 ( $1=$ Least important, $5=$ Very important), rate the importance of the factors (listed in Table 3) in the planning and designing of the latest construction development that the Key Player have participated in. In addition, rate how they believed these factors should influence the planning and designing of a low-carbon community. These factors were established based on typical considerations by project teams during the pre-design and design stages, which sets the parameters for all decisions in the following phases. For instance, if the Architect's Design Concept was highly influential and the Architect's vision is to design a high-performance and efficient building, this would impact the overall aesthetics of the building, the glazing-to-wall ratios, the performance of the envelope, the systems selection, and 
maybe even the functional spacing within the building. On the other hand, if the Architect's vision was to create a visually attractive building which consists of floor to ceiling glazing, then the performance of the building may have to be sacrificed. The intent of Group 1 questions is to understand what the key players believe to be important considerations when designing a low-carbon building / community, and how that differs with their most recent project experience. The results should be aligned to successfully adopt low-carbon design.

Table 3: List of influencing factors for the planning and designing of a construction development Index of influencing factor Particular of the Influencing Factor ( $i$ in Equation 1)

\begin{tabular}{|c|l|}
\hline 1 & Architect's Design Concept \\
\hline 2 & Client's Project Scope \\
\hline 3 & Site Characteristics \\
\hline 4 & Weather Conditions \\
\hline 5 & User-Group Preferences \\
\hline 6 & Public Transportation \\
\hline 7 & Project Budget \\
\hline 8 & Project Goals (I.e. Energy Efficiency, Green Attributes etc.) \\
\hline 9 & Site Selection \\
\hline 10 & Available Resources (i.e. Materials) \\
\hline 11 & Construction Techniques / Methodology \\
\hline 12 & Construction Schedule \\
\hline 13 & Sales / Rental Price \\
\hline 15 & Waste Treatment \\
\hline
\end{tabular}

For each one of the influencing factors listed in Table 3, individual professionals were asked to rate the level of importance (i) in a range of 1 to $5(j=1$ to 5$)$, with 1 representing the least important and 5 most important.

The importance is rated based on previous projects that the responding professional has participated in, and on the importance in a low-carbon development. 
The frequency of responses to $i$-th influential factor being equal to $j(j=1,2, \ldots 5,1=$ least important, 5= most important), is (Liao, 2013):

\section{$f(i, j)$ for rating based on previous projects}

$$
p(i, j) \text { for rating based on low - carbon scenario }
$$

The overall rating based on all valid responses is calculated as follows (Liao, 2013):

$$
\begin{aligned}
& F(i)=\frac{\sum_{j=1}^{5} f(i, j) w(j)}{\max (w(j)) \cdot \sum_{j=1}^{5} f(i, j)}=\frac{1}{5 N} \sum_{j=1}^{5} f(i, j) w(j) \\
& P(i)=\frac{\sum_{j=1}^{5} p(i, j) w(j)}{\max (w(j)) \cdot \sum_{j=1}^{5} p(i, j)}=\frac{1}{5 N} \sum_{j=1}^{5} p(i, j) w(j)
\end{aligned}
$$

Where,

$\mathrm{N}$ is the total sampling size or the number of valid responses.

Weighting factors $w(j)=j, j=1$ to 5

For any influencing factor ( $i, i=1$ to 15 , see also Table 3$)$, the difference between $F(i)$ and $P(i)$ indicates the discrepancy on the importance placed on individual factors between the current practice and low-carbon scenario:

- When $F(i)>P(i)$, the influencing factor (i) is over-considered by current practice. When designing a low-carbon development, the importance of this factor can be reduced.

$\circ$ When $F(i)<P(i)$, the influencing factor (i) is not considered sufficiently by current practice compared with the requirement of the low-carbon scenario. 
Group 2: Within a range of 1 to $5(1=$ Least important, $5=$ Most important), rate the importance of the basic components/attributes of a typical community (listed in Table 4) on the marketability, carbon emission, environment and life quality of occupants. The components/ attributes of this set of questions are based on the design impacts on a community scale. For instance, building aesthetics affect more than just the building itself as it may interfere with the overall street facade, views from adjacent buildings, or shadows casts on the streets. Interestingly, individual components may vary in importance when considering for marketability, carbon emission, environment and life quality of occupants. For example, having extensive parking may be a highly marketable, but it encourages passenger vehicle use which may be detrimental from a carbon emission reduction and environmental perspective. Part of these discrepancies is related to the community's attitude, understanding and commitment to low-carbon buildings/ community. To truly achieve low-carbon development, it is important for the community to shift its current living patterns, and having the necessary infrastructures to preserve the quality of life. If an affordable and comprehensive public transportation is available and various amenities are within walking distance to an individual's workplace, they may be more inclined to use the transit system which reduces passenger vehicles use. 


\section{Table 4: Basic components/attributes of a typical community}

\begin{tabular}{|c|l|}
\hline Index & \multicolumn{1}{c}{ Particular of Components / Attributes } \\
\hline 1 & Building Aesthetics \\
\hline 2 & Building Envelope \\
\hline 3 & Building Mechanical Systems \\
\hline 4 & Quality of the Building \\
\hline 5 & Building Floor Area Ratio \\
\hline 6 & Community Density \\
\hline 7 & Green Space / Landscape \\
\hline 8 & Parking \\
\hline 10 & Public Transportation \\
\hline 11 & Proximity to Entertainment Facilities (i.e. cinemas, parks, community center etc.) \\
\hline 12 & Proximity to Childcare / School / Senior Care Facility \\
\hline 13 & Proximity to Commercial Buildings (i.e. retail, offices etc.) \\
\hline 14 & Proximity to Grocery Shops \\
\hline 15 & 3rd Party Certification (i.e. LEED, BOMA BESt, etc.) \\
\hline
\end{tabular}

In this study, the performance of a community is measured by four variables: marketability, carbon emission, quality of environment and quality of living. These are integrally determined by all the components and/or attributes of a community, as listed in Table 4 that are designed, built and maintained according to the influential factors considered in the process of development, studied by questions in Group 1.

For each of the four performance measurements, individual professionals were asked to rate the importance of all community components/attributes $(i=1,2, \ldots 13$, see Table 4$)$ in a range of 1 to $5(j=1,2, \ldots 5,1=$ Least Important, $5=$ Most Important). The frequency of responses is as follow:

- The importance of individual component/attribute (i) on Marketability being equal to $j: m(i, j), j=1,2, \ldots, 5$. 
- The importance of individual component/attribute (i) on Level of Carbon Emission being equal to $j: c(i, j), j=1,2, \ldots, 5$.

- The importance of individual component/attribute (i) on Level of Quality of Environment being equal to $j: e(i, j), j=1,2, \ldots, 5$.

- The importance of individual component/attribute (i) on Quality of Living being equal to $j: l(i, j), j=1,2, \ldots, 5$.

The overall rating based on all valid responses is calculated as follow (Liao, 2013):

$$
\begin{aligned}
& M(i)=\frac{\sum_{j=1}^{5} m(i, j) w(j)}{\max (w(j)) \cdot \sum_{j=1}^{5} m(i, j)}=\frac{1}{5 N} \sum_{j=1}^{5} m(i, j) w(j) \\
& C(i)=\frac{\sum_{j=1}^{5} c(i, j) w(j)}{\max (w(j)) \cdot \sum_{j=1}^{5} m(i, j)}=\frac{1}{5 N} \sum_{j=1}^{5} c(i, j) w(j) \\
& E(i)=\frac{\sum_{j=1}^{5} e(i, j) w(j)}{\max (w(j)) \cdot \sum_{j=1}^{5} m(i, j)}=\frac{1}{5 N} \sum_{j=1}^{5} e(i, j) w(j) \\
& L(i)=\frac{\sum_{j=1}^{5} l(i, j) w(j)}{\max (w(j)) \cdot \sum_{j=1}^{5} m(i, j)}=\frac{1}{5 N} \sum_{j=1}^{5} l(i, j) w(j)
\end{aligned}
$$

Where,

$\mathrm{N}$ is the total sampling size or the number of valid responses.

Weighting factors $w(j)=j, j=1$ to 5

Group 3: Within a range of 1 to 5, rate the practicality (1= Least Practical, 5= Most practical), effectiveness (1= Least Effective, 5= Most Effective) of design strategies or technologies for lowcarbon development listed in 
Table 5. In addition, the key player will identify whether they have experience (No Experience, Experienced) and their awareness of the availability of any related tools (Not Available, Available) with the design strategies or technologies listed in Table 5. The questions in Group 3 are designed to evaluate design strategies / technologies on a building scale. The strategies are known solutions to developing low-carbon buildings, yet they may not be fully utilized because of their practicality or effectiveness. When evaluating the practicality of an individual strategy/ technology, one may look at life-cycle costing, or whether it makes sense given the design parameters. For instance, solar shades may be a cost-effective solution to controlling solar heat gain, yet in a building designed to maximize daylight and views, it may not be a very practical solution. The second part of this set of question focuses on the effectiveness of individual strategies/ technologies for low-carbon building development. Does it really make a difference in reducing carbon emission? Lastly, the study will attempt to understand how often these strategies are being used and whether supporting tools are available. Individual design strategies/ technologies may be highly practical and effective, but if no one has the knowledge, experience and tools to use them, they will simply not be used in projects. This section is particularly important because it identifies the gap (if any) between the current status of the industry and where it needs to be towards low-carbon development. 


\section{Table 5: Design strategies or technologies for low-carbon development}

\section{Index Particular of design strategies or technologies for low-carbon building development}

1 Designing the building shape to maximize natural ventilation

2 Building Envelope - increase building insulation, reduce air leakage

3 Storm Water Management Strategies (on a building scale)

$4 \quad$ Storm Water Management Strategies (on a campus scale)

5 Dimmable lighting, maximizing daylight

6 Energy efficient lighting design (Indoors and outdoors)

7 Shading devices to control solar heat gain

8 Select a reasonable construction equipment system and optimize its design, selection of energy efficient equipment

9 Building Automation System

10 Increase vegetation / plant drought resistant or native species

11 Zoning for HVAC design

12 Geothermal

13 Distribute public / community buildings evenly around the community within walking distance to encourage travelling by feet

14 Centralized heating systems with Individual meters

15 Solar water heating

16 Green roof

17 Urban agriculture, rooftop gardens

18 Optimize community circulation

19 3rd Party Certification (i.e. LEED, BOMA BEST, etc.)

The questions in Group 3 are aimed to determine the effectiveness of the current industry's design practices towards developing low-carbon buildings and communities, and how well they are equipped with the relevant knowledge, skills and tools.

Individual professionals are asked to rate, according to their own experience from previous projects, the practicality, effectiveness, level of skill and experience, and awareness of relevant tools of the nineteen design strategies/technologies for low-carbon development (listed in 
Table 5). The rating is between 1 and 5, with 1 corresponding to least effective and 5 most. A calculation method similar to that used in Equation (3) to (8) is used to determine the overall rating of Practicality $\left(f_{s}\right)$, Effectiveness $\left(e_{s}\right)$, level of skill and experience $\left(s_{s}\right)$, and awareness of tools $\left(t_{s}\right)$.

The level of success that a design strategy or technology can have on the development of a lowcarbon residential community depends on all the four variables $\left(f_{s}, e_{s}, s_{s}, t_{s}\right)$. We define the Probability of Successfully Using a design strategy/technology as (Liao, 2013):

$$
p(i)=f_{s}(i) * e_{s}(i) *\left(1-\exp \left(-s_{s}(i) *(1-\alpha)-t_{s}(i) * \alpha\right)\right)
$$

Where,

$i=1,2, \ldots, 19$, corresponding to the nineteen design strategies/technologies listed in Table 5

The rationale for the design and formulation of the questionnaire follows the sequence of pertinent events or decision-making in the process of construction development community (Refer to Figure 12). All the considerations studied in Group 1 need to be taken into account in the process of project development to set the parameters for evaluation of the community components studied in Group 2. Questions in Group 3 are associated with knowledge and technologies that need to be integrally employed in the buildings in order to meet the expectations. 


\section{Findings}

The questionnaire was distributed to individual professionals with a minimum of 5 years

Ontario industry experience through relevant professional organizations. All distribution

flowed through a single individual, therefore all instructions and clarifications were identical to all participants. 70 copies were distributed and 29 valid responses were received. The responding rate of $47 \%$ reflects the industry's support for academic research related to lowcarbon development. The sample size of responding individuals may not significantly represent the population of relevant professionals working in Ontario, but individuals from all Key Player groups have been represented in the study therefore the results are still valid.

Group 1: Importance of influencing factors on the planning and design of a low-carbon community.

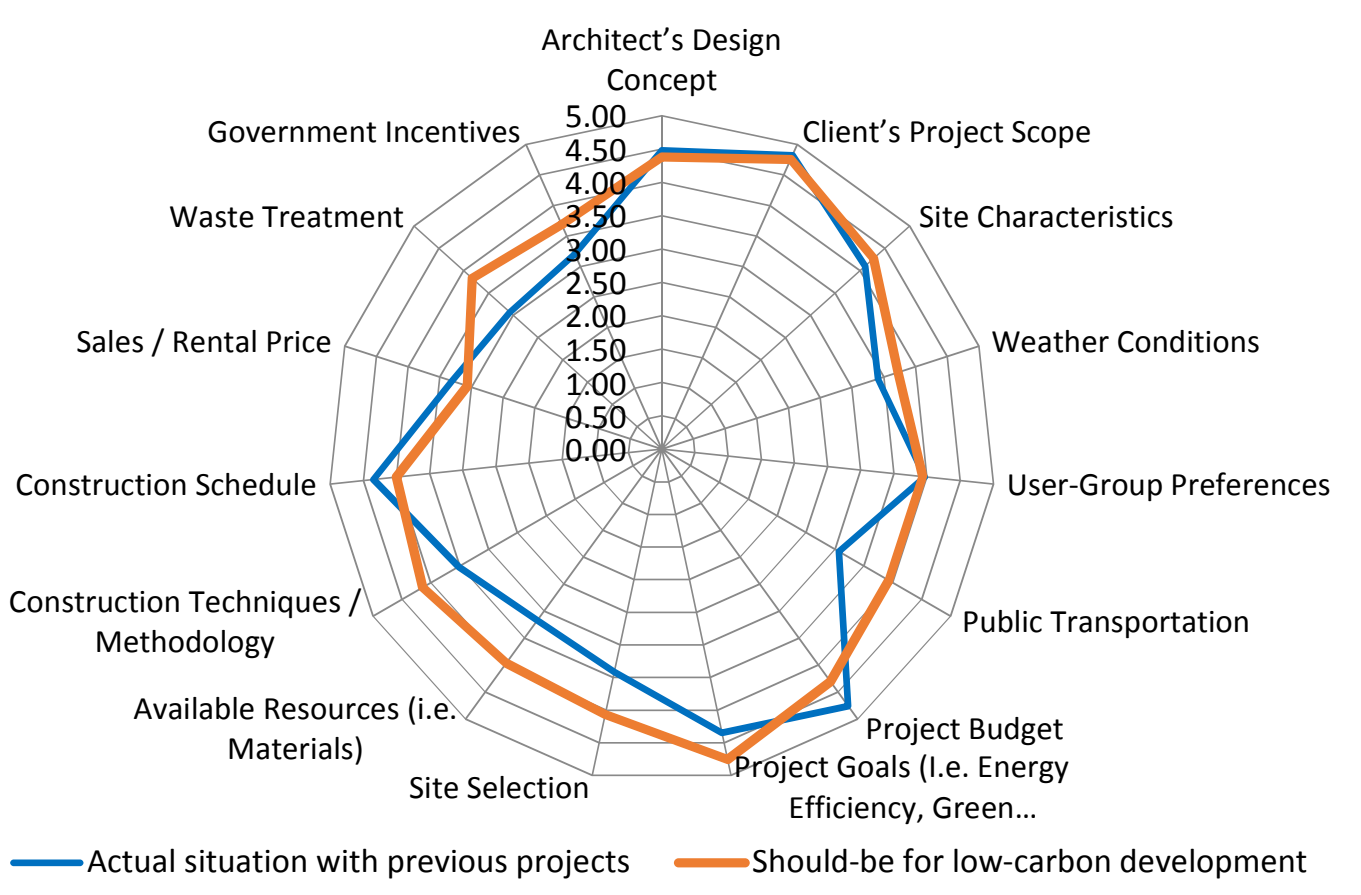

Figure 13: Overall rating of fifteen influencing factors: a comparison between the actual situation with previous projects and low-carbon scenario 
Figure 13 compares the overall rating of all fifteen influencing factors between the actual situations with previous projects and the ideal level of influence under the low-carbon scenario. The results can be classified into three categories:

- Factors where F are greater than P: Project Budget, Construction Schedule, Sales/Rental Price.

- Factors where P are greater than F: Site Characteristics, Weather Conditions, Public Transportation, Project Goals, Site Selection, Available resources, Construction Techniques / Methodology, Waste Treatment, and Government Incentive.

- Factors where $\mathrm{P}$ and $\mathrm{F}$ are very close: Architect's Design Concept, Client's Project scope, and User Group Preferences.

Based on the results above, the factors where $F$ is greater than $P$ identifies factors which are over-considered by the current industry. All three factors within this category are highly related to the financial aspects of the project. This indicates that the current practice is dominatingly controlled by the issues that are directly or indirectly related with financial aspects of a project, such as the budget, schedule and the targeted property price.

In the second group where $\mathrm{P}$ is greater than $\mathrm{F}$, these factors are believed to be insufficiently considered in the current practices; especially in a low-carbon development scenario. All the factors within this category are relatively technical, except for government incentive which is related to the project finances. This may represent the industry lacks knowledge of available government incentives, the unavailability or limited amount of government incentives, or the 
incentives themselves do not contribute adequately to the project to make an impact. Further studies may be required to understand the results for this factor.

The factors which belong to the group where $\mathrm{P}$ and $\mathrm{F}$ are very close represent the current practice is dealing with these three issues with the right level of rigor. The three factors within the group are all very subjective and relates to what people want - the architect, client or the end users. This represents the current industry is adequately considering and balancing the needs of all parties (the owner, the designers and the end users).

Group 2: The evaluation of components and attributes of a community based on marketability, carbon emission, quality of environment and quality of living.

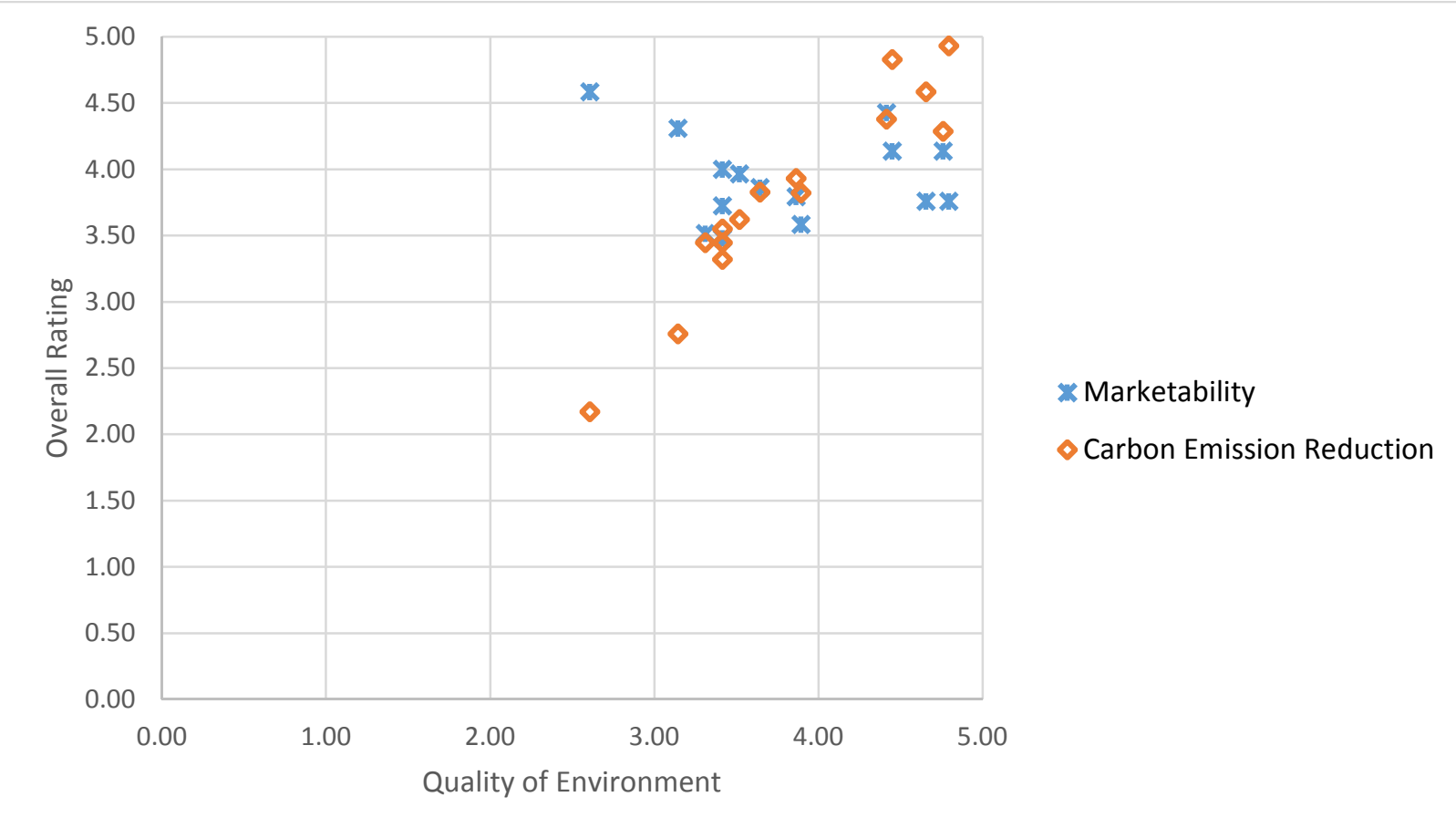

Figure 14: Correlation between Quality of Environment and Marketability, Carbon Emission 
Figure 14 shows the correlation between quality of environment with marketability, and carbon emission. Generally speaking, the key players believe that the quality of environment affects both the marketability and carbon emission of the community. A higher quality of environment results in better marketability and higher carbon emission reduction. Looking at the two evaluation criteria separately, the relationship between carbon emission reduction and the quality of environment is much stronger than compared to marketability. This is true because the amount of carbon emission reduction directly affects the quality of the environment. To reduce carbon emissions, communities must adopt strategies that reduces the burning of fossil fuels, which in turn creates a healthier environment (i.e. lower reliance on single vehicle usage).

When comparing marketability and the quality of environment, the relationship is rather scattered. In many cases, factors scoring high quality of environment are also highly marketable, because quality of the environment is a marketable trait. This shows the general public are aware of the importance and benefits of living in a community that is environmentally friendly. However, there are also factors that are highly marketable but may not directly contribute to the quality of the environment - such as building aesthetics and safety. These two components may not impact the quality of the environment, yet it alters the user's experience. 


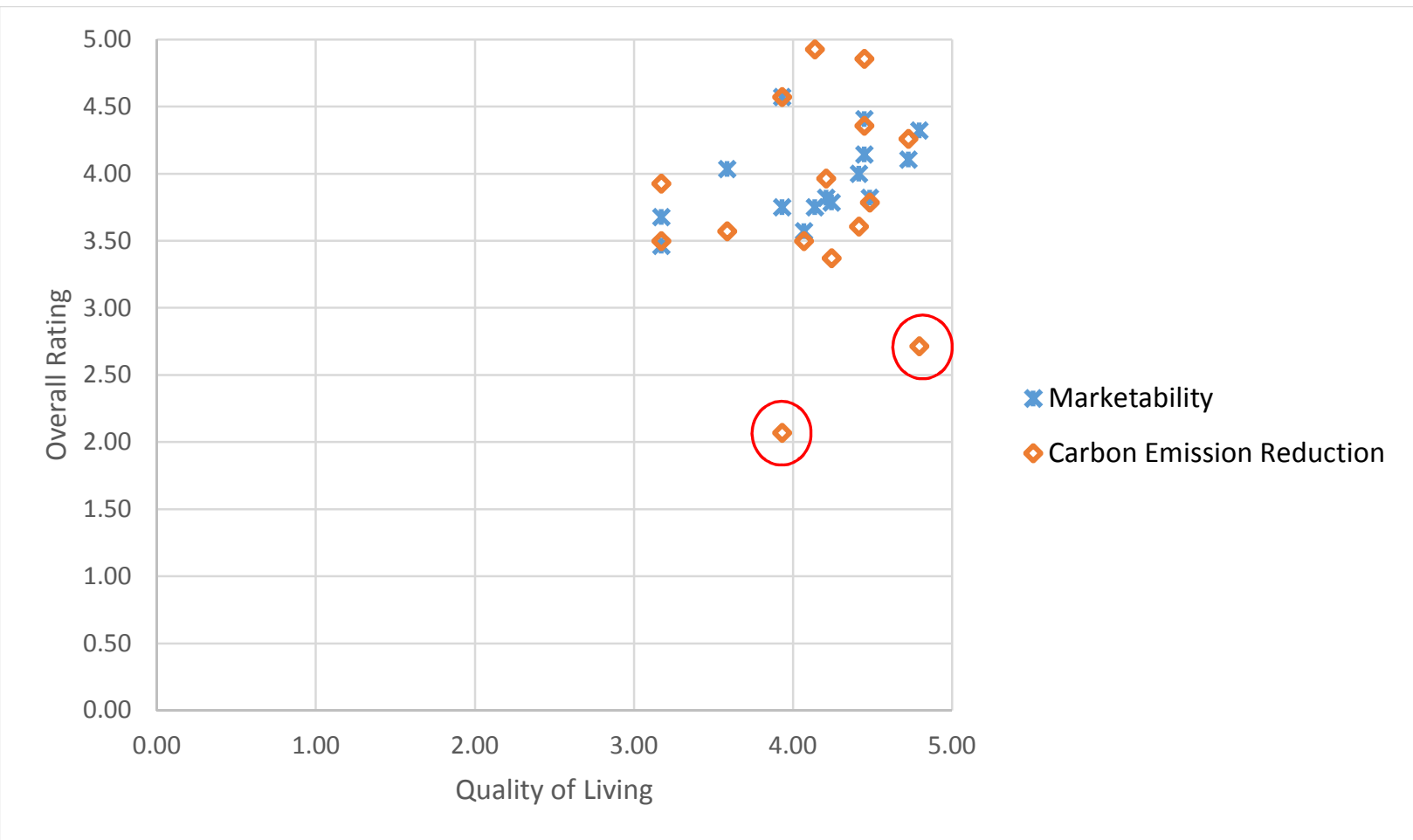

Figure 15: Correlation between quality of Living and Marketability, Carbon Emission

Figure 15 presents the correlation between the quality of living in a low-carbon community and the marketability versus carbon emission. There is no distinct relationship between the quality of living with marketability and carbon emission reduction, except majority of the components are regarded to be highly marketable, helps reduce carbon emission, and provides a good quality of living (all rated between $3-5$ of importance). The only exception is building aesthetics and safety (circled above) which is shown to improve the quality of living yet makes no contribution towards carbon emission reduction. 


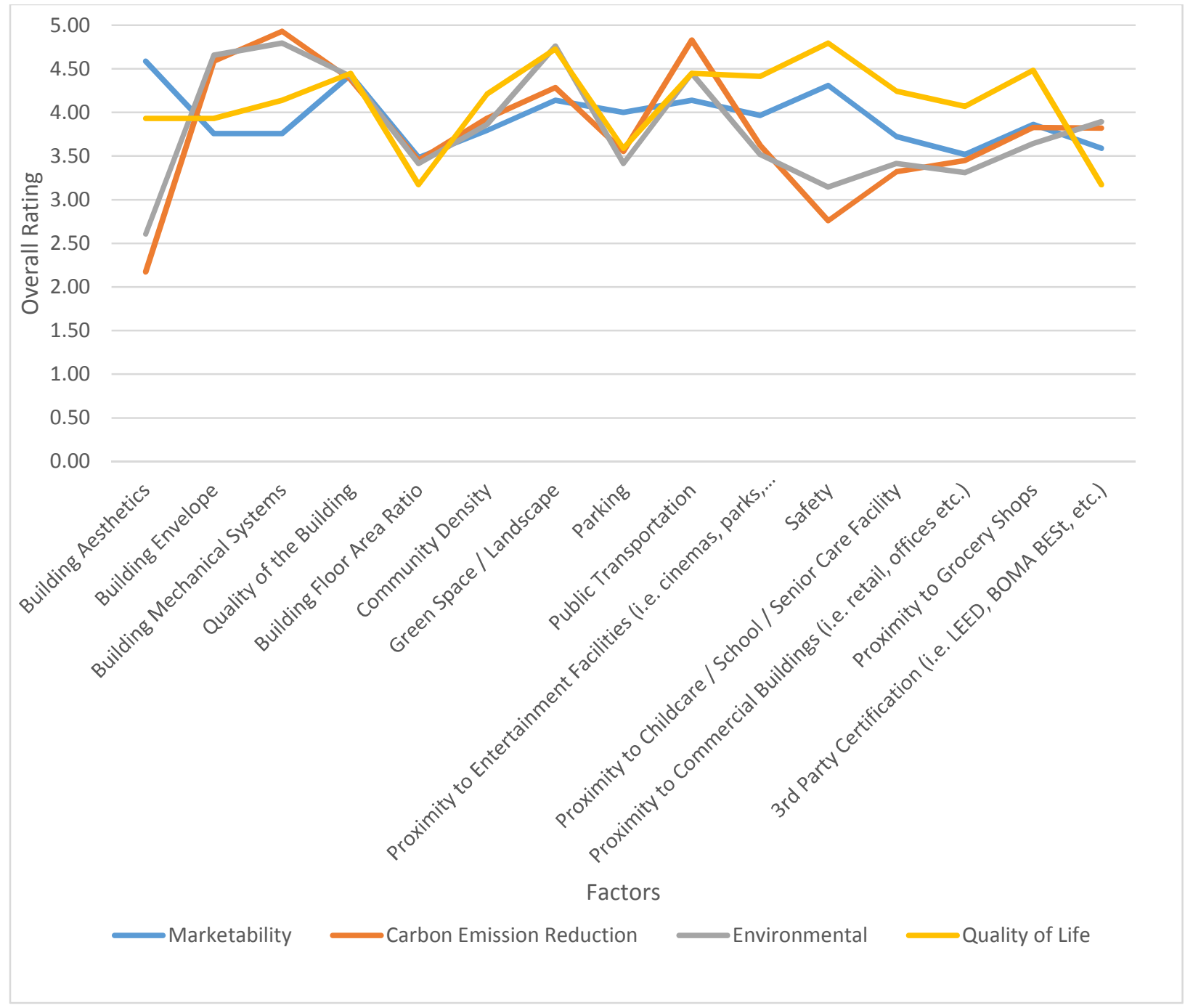

Figure 16: Importance of various factors in relation to marketability, carbon emission reduction, environment and quality of life

Figure 16 outlines the relationship between marketability, carbon emission reduction environment and quality of life for each factor shown in Table 4Table 5, which is summarized below:

Building Aesthetics: Building aesthetics is the most marketability factor from the table, yet it is identified to be the least effective towards carbon emission reduction. This is true because it relates to the 'beautify' factor of the development, appealing to the user's preferences (therefore marketable) rather than the environmental benefits. 
Building Envelope: Building envelope is shown to highly contribute towards carbon emission reduction and the environment, and less impact towards marketability and the quality of life. This represents the key players are aware of the importance of having a good building envelope system (i.e. window to wall ratios, insulation etc.) towards carbon emission reduction and the environment. It also shows they are aware of the benefits towards the building occupants (i.e. less temperature draft, heat gain / heat loss from the windows etc.) which makes this factor also favorable from a marketing and quality of life perspective.

Building Mechanical System: This factor is shown to be the most important when trying to achieve carbon emission reduction. The burning of fossil fuels directly impact the amount of carbon emission therefore if projects are able to reduce / eliminate the need to burn fossil fuels for energy by harvesting energy, using more efficient / high performance systems etc., carbon emission will be highly reduced. The relatively high scores in the quality of life and marketability shows that a good building mechanical system also provides comfort and the general public is aware of its benefits.

Quality of the Building: This factor is shown to have an almost-equal rating across all four evaluation criteria. The quality of the building will affect the longevity, serviceability, and the ongoing maintenance of the building therefore a good quality building benefits the users and the environment.

Building Floor Area Ratio: This factor is fairly 'neutral' when evaluated by all four evaluation criteria. The building floor area ratio impacts the density of the development, which affects carbon emission and in turn the environmental quality of 
the building. When evaluating this factor from a community scale, it appears the key players believe this factor does not go for or against each of the evaluation criteria.

Community Density: This factor is similar to Building Floor Area Ratio, but on a community scale. The key players believe this factor is fairly important for all four evaluation criterion as a denser community reduces transportation and their respective infrastructures, which also increases the marketability and quality of life of the occupants.

Green Space / Landscape: Based on the survey results, this factor is very important from an environmental and quality of life standpoint, and slightly less important for marketability and carbon emission reduction. Increased vegetation directly improves the environment and provides places of respite for the community.

Parking: This factor is relatively important from a marketability standpoint, and less important towards carbon emission reduction, environmental and quality of life. Although the convenience of having parking encourages driving which in turn hurts the environment and carbon emission reduction, yet the question asks the individual to rate the importance of each factor. As a result, the rating for this factor is still fairly high for all four evaluation criteria although it does not contribute positively towards carbon emission reduction and the environment.

Public Transportation: Public transportation is identified to be very important for all four evaluation criteria. Based on Figure 9, transportation is the largest contributor towards carbon emission. A good public transportation system encourages the public to 
utilize this means of transportation instead of vehicles, which in turn improves the quality of life of the individual, reduces carbon emission (from vehicle use and infrastructure), improves the environment, and therefore making it highly marketable.

Proximity to Entertainment Facilities: Entertainment is very important from a quality of life perspective. Having close proximity to these facilities helps reduce the amount of transportation required, which also benefits the carbon emission related to travelling, and therefore improving the environment.

Safety: The sense of living in a safe environment is extremely important from a quality of life perspective. This factor is directly related to the human sector and less towards the environmental and carbon emission reduction criteria.

Proximity to Childcare/ School/ Senior Care Facility: Similar to entertainment facilities, these facilities are very important to the general public. Having these facilities in the community provides convenience and reduces the negative impacts of travelling. Based on the survey results, this factor is very important from a quality of life perspective, but less for carbon emission reduction and environment.

Proximity to Commercial Buildings: Interestingly, this factor is shown to be very important from a quality of life perspective, and relatively neutral for the other three evaluation criterion. Being close to retail and other commercial buildings may be advantageous to one's everyday life, but many of these buildings also provide employment. The benefits of living near your work does not seem to have been considered by the key players. 
Proximity to Grocery Shops: This factor is shown to be relatively important for all four evaluation criteria as groceries are essential to everyday life. Being close to grocery shops. Having close proximity to grocery shops reduce the amount of transportation required, which also benefits the carbon emission related to travelling, and therefore improving the environment.

$3^{\text {rd }}$ Party Certification: Interestingly, this factor is fairly important for Marketability, carbon emission reduction and environment, and neutral for the quality of life. Different certifications evaluation different things but majority of these certifications (i.e. LEED, BOMA BESt) will take the environmental quality of the building into account therefore the quality of life should be improved for buildings that have undergone a $3^{\text {rd }}$ party certification. This shows the key players may not be very familiar with the parameters of $3^{\text {rd }}$ party certifications. 
Group 3: The evaluation of the effectiveness, practicality, level of skills, and experience and awareness of relevant tools for low-carbon development.

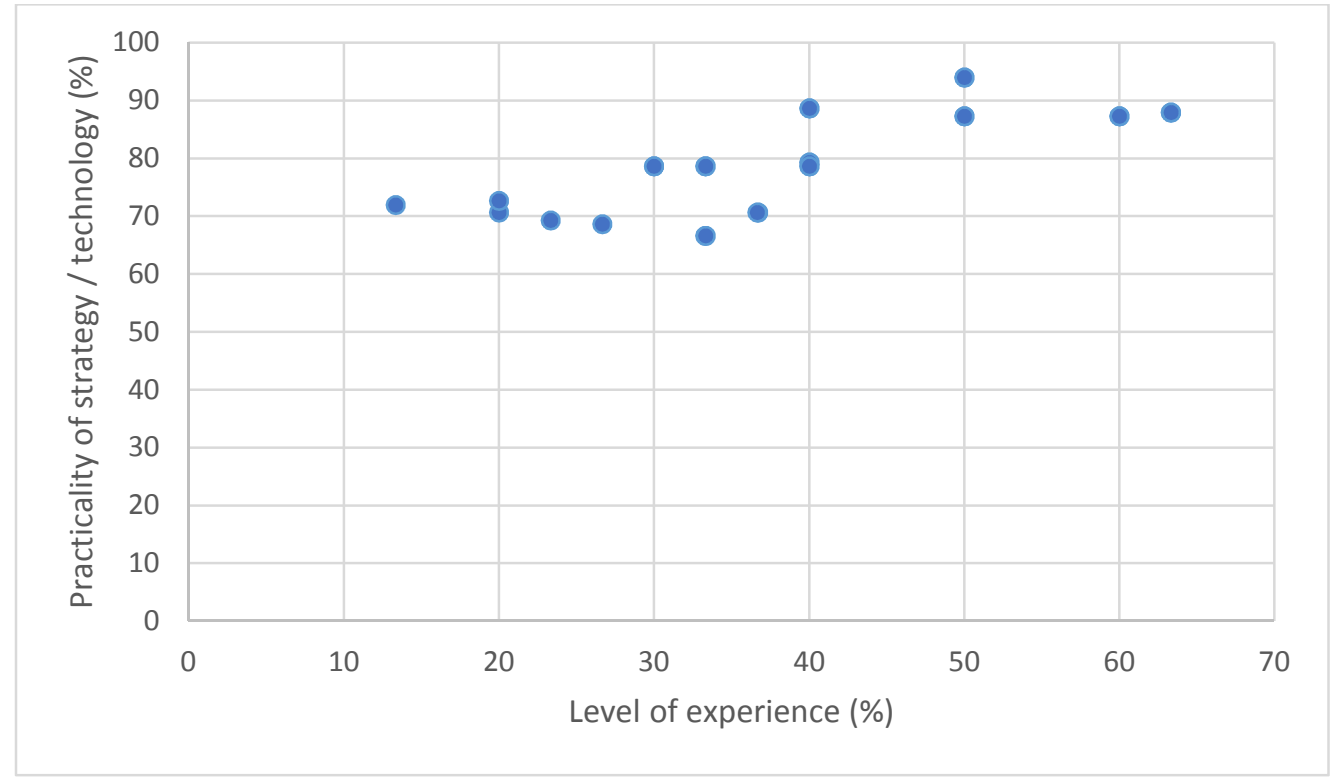

Figure 17: Relationship between the practicality of strategy / technology and level of experience

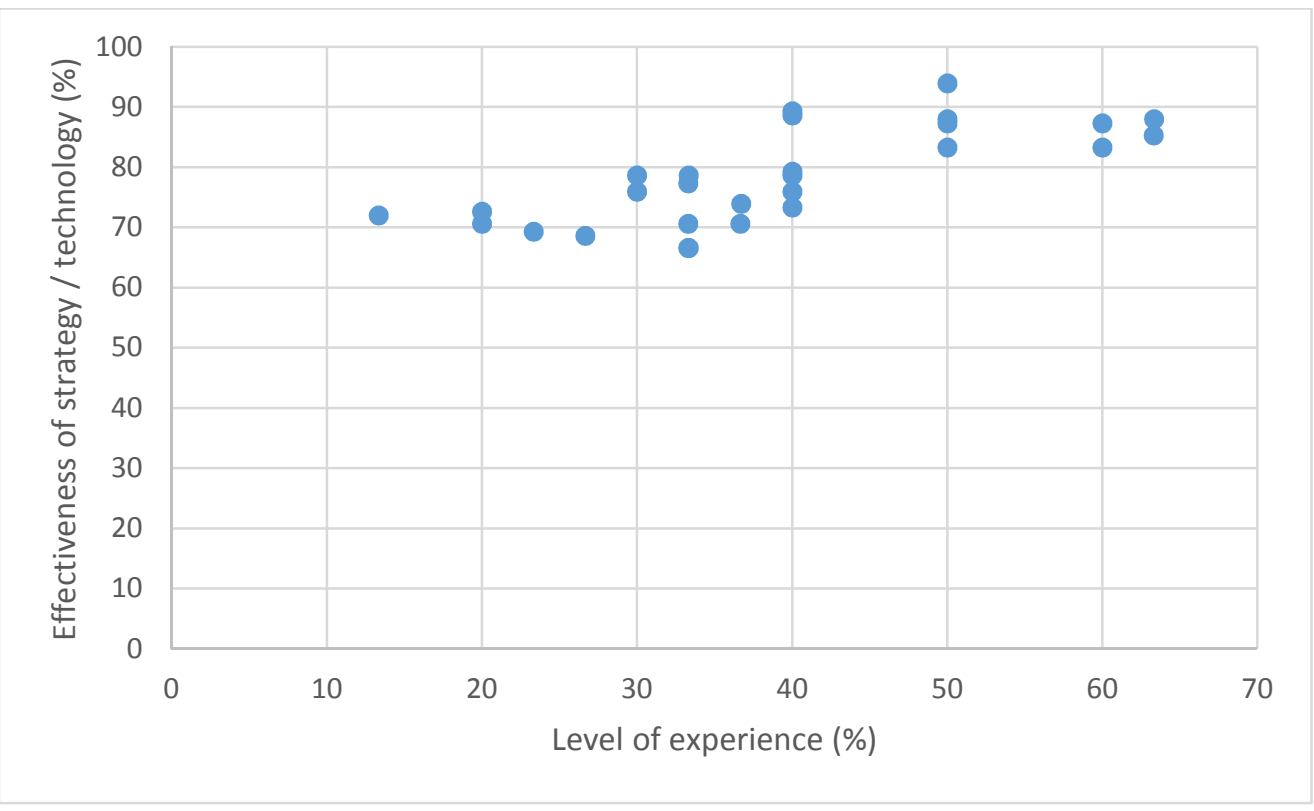

Figure 18: Relationship between the effectiveness of strategy / technology and level of experience 
Figure 17 and Figure 18 demonstrate how the level of experience of a specific strategy / technology affects the perceived practicality, effectiveness and probability of successful application of the design strategies/technologies. These figures indicate:

- The professionals surveyed have very low level of experience with the design strategies/technologies considered in this study, ranging between 13 and 65 in a normalized scale of 100 .

- Both the perceived practicality and effectiveness of the design strategies/technologies are loosely correlated to the level of experience. It was expected that the measures that make financial sense (practical) will likely be used more often (more experience), and the more experience one has will make them more competent towards using that strategies/technologies (effective). However, based on the data above, the relationship between perceived practicality, effectiveness and level of experience is fairly weak. 


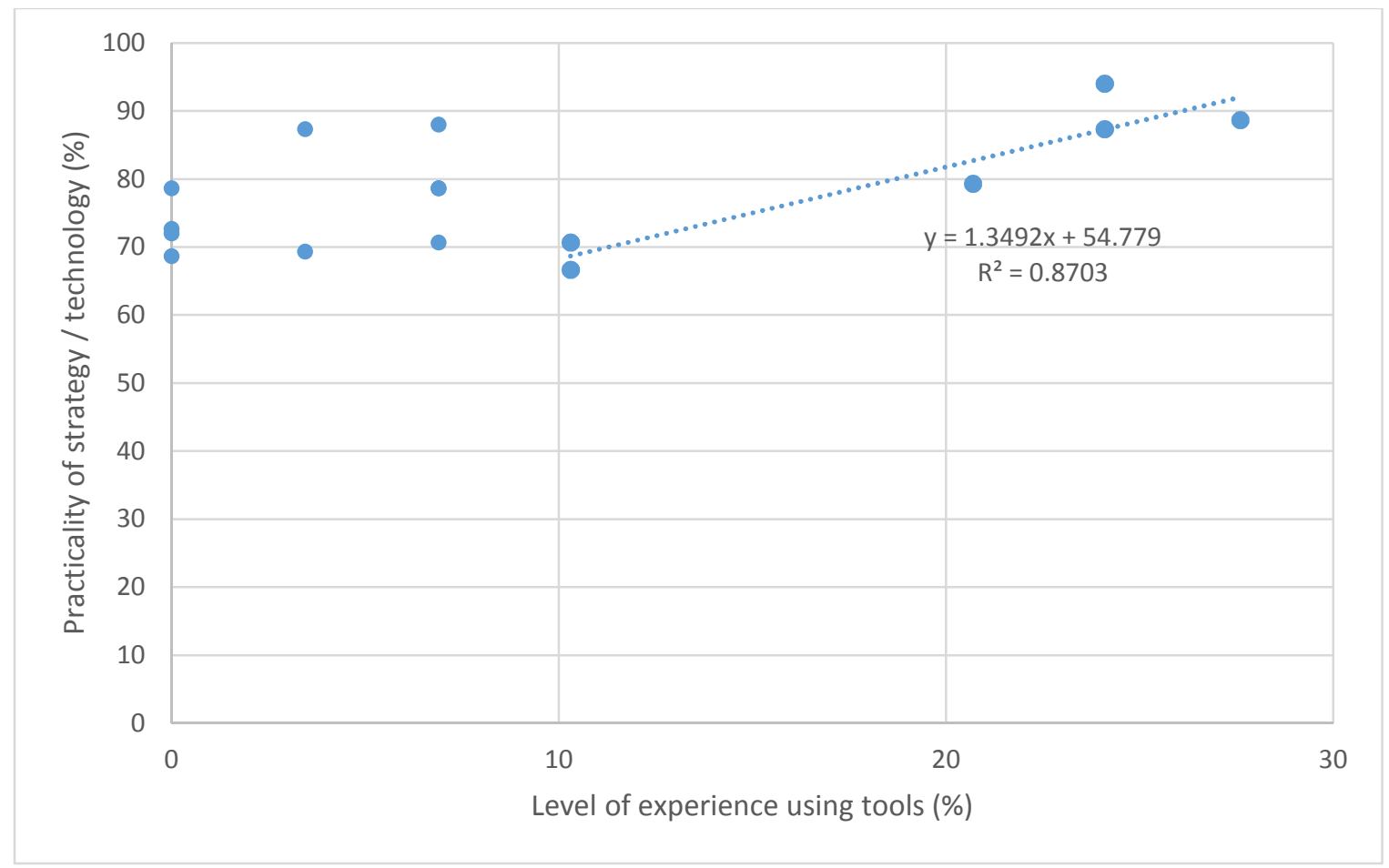

Figure 19: Relationship between practicality of strategy/technology and level of experience using tools

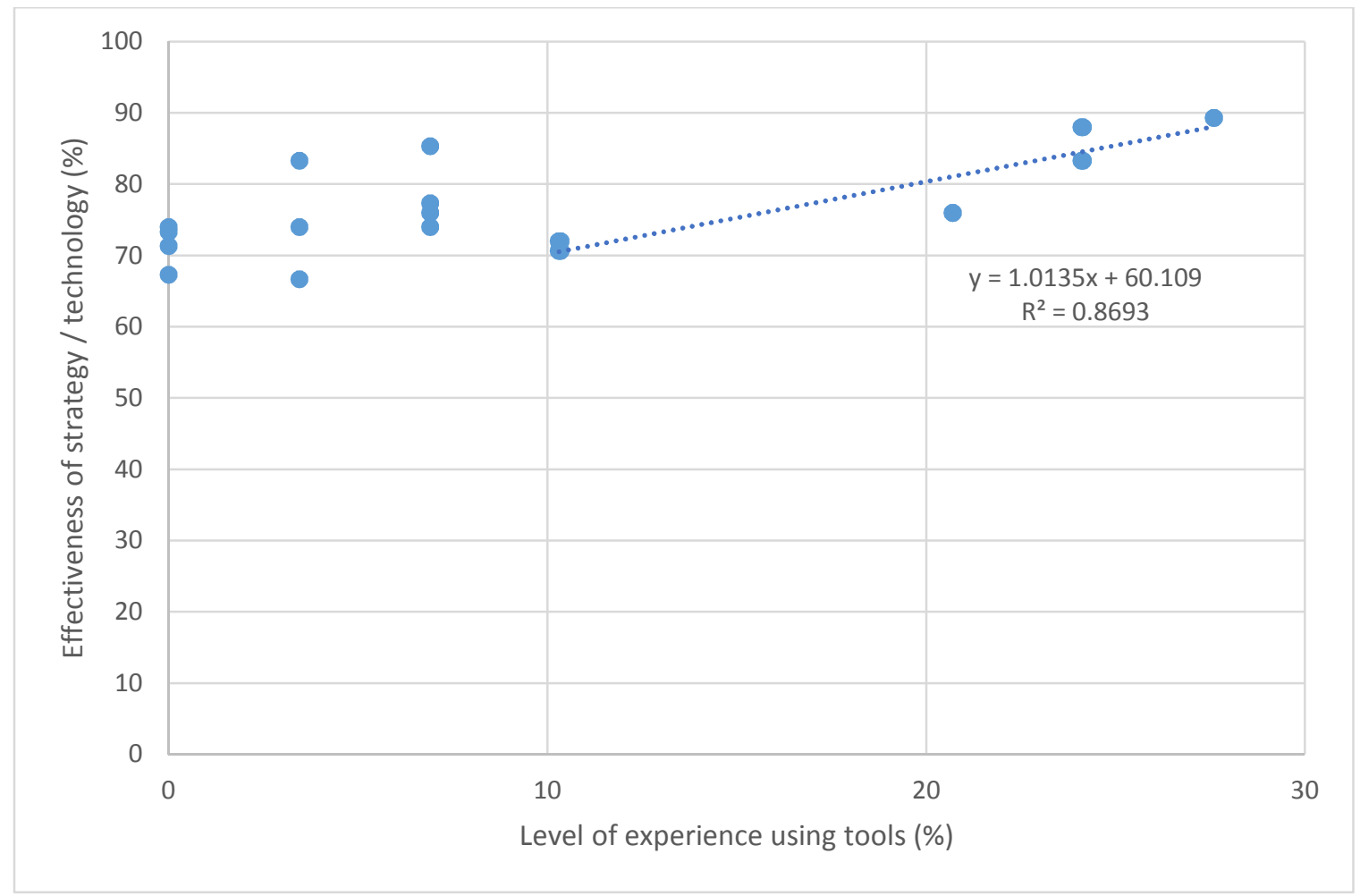

Figure 20: Relationship between effectiveness of strategy / technology and level of skill using tools 
Figure 19 and Figure 20 shows how the practicality and effectiveness of design strategies are affected by the availability and the level of skills of key players using relevant supporting tools, including those used in the design processes and for performance modeling. The level of skills and experience of using individual tools and technologies affect the key player's perceived practicality and effectiveness of the strategy, which in turn affects the probability of the successful use of the design strategies/technologies. These figures indicate:

- The professionals surveyed are not sufficiently aware of any tools or have a very low level of skill using assisting tools for the design strategies/technologies considered in this study, ranging between 0 and 28 in a normalized scale of 100 . This could be due to the lack of tools available in the industry, lack of knowledge of what's available, or that the use of such tools is simply not required in the vast majority of their projects. Design strategies/ technologies where key players identify to have no experience with the tools include: Increasing vegetation/ plant drought resistant or native species, distributing public/ community buildings evenly around the community within walking distance to encourage travelling by feet, urban agriculture, rooftop gardens, and optimizing community circulation.

- Based on the previous point, all data where the professionals identify to have no to little experience with any relative tools to support the use of individual strategies / technologies are excluded. Only data with a minimum of experience of $10 \%$ or above are analyzed. Based on the remaining data, the perceived practicality and effectiveness of the design strategies/technologies are highly correlated to the level of skills (and availability) of using assisting tools. These tools help the professionals 
better understand the strategies/technologies such that their application in practice becomes more manageable.

- High level of skill using assisting tools allow for a more successful application of the design strategies/technologies.

These observations have created a dilemma: the professionals in the local industry have very low level of experience using strategies and technologies which are known for low-carbon development, and even lower level of skills and knowledge using assisting tools (which may be due to the lack of available tools); and having sufficient experience and skills using assisting tools is extremely important for low-carbon development. Future studies may include investigating and evaluating available tools and technologies, and identifying where efforts are needed to support industry professionals. In addition, the development of training programs is essential to fill the gap between current industry practices and low-carbon development.

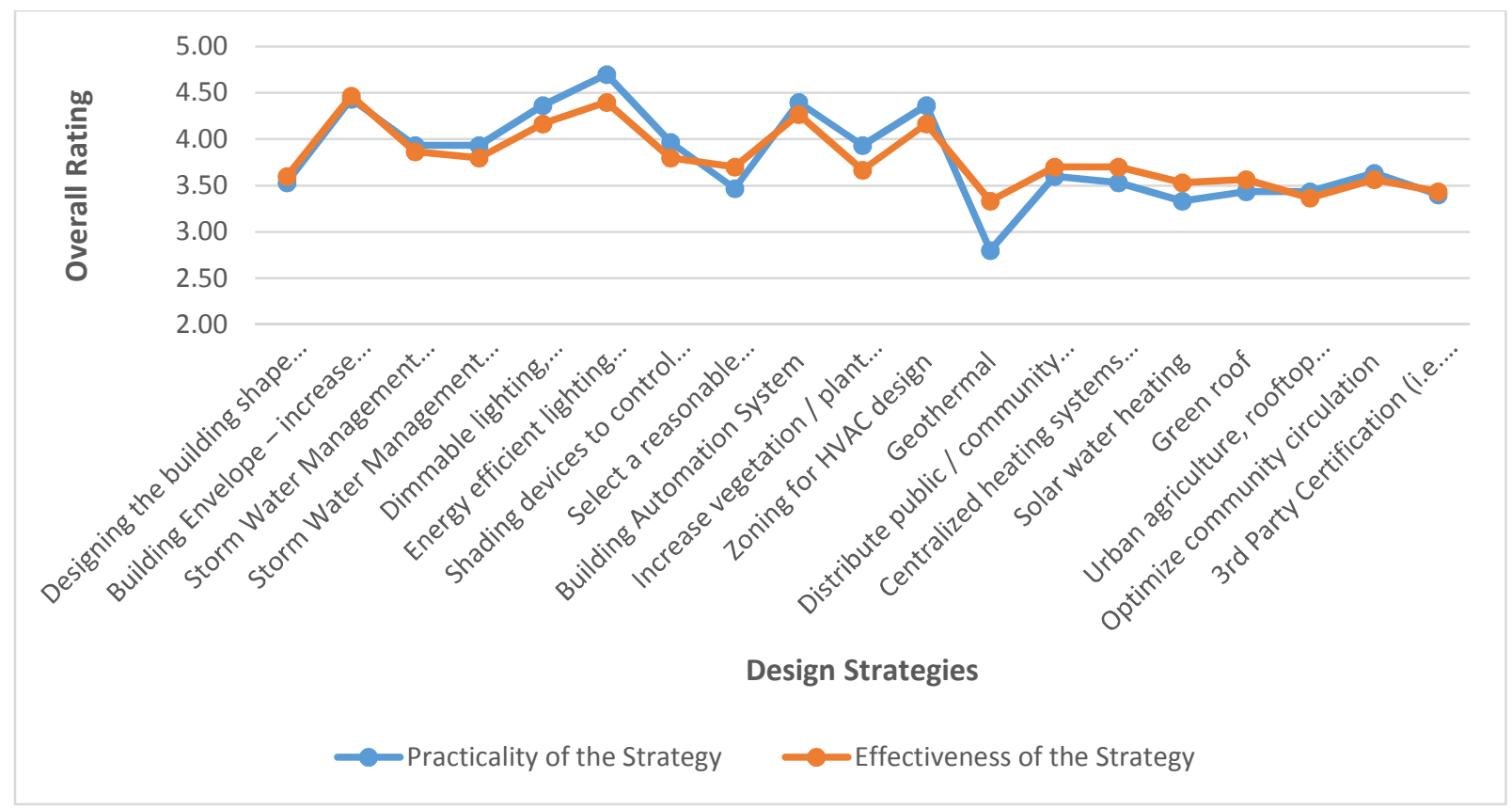

Figure 21: Comparison between the practicality and effectiveness of individual design strategies. 
Figure 21 examines the relationship between the effectiveness and practicality of individual strategies / technologies. Using similar equations for evaluating Group A data (Equations 3 and 4), the results can be classified into three categories:

○ Factors where Practicality > Effectiveness: Strategies / technologies in this category represent a good investment based on the benefits it yields.

- Storm Water Management Strategies (on a building scale)

- Storm Water Management Strategies (on a campus scale)

- Dimmable lighting, maximizing daylight

- Energy efficient lighting design (Indoors and outdoors)

- Shading devices to control solar heat gain

- Building Automation System

- Increase vegetation / plant drought resistant or native species

- Zoning for HVAC design

○ Factors where Effectiveness > Practicality: Strategies / technologies in this category represent a less favorable investment based on the benefits it yields.

- Select a reasonable construction equipment system and optimize its design, selection of energy efficient equipment

- Geothermal

- Centralized heating systems with Individual meters

- Solar water heating, Green Roof

Factors where Effectiveness and Practicality are very close: Factors in this category represents a fair investment based on the benefits it yields.

- Designing the building shape to maximize natural ventilation

- Building Envelope - increase building insulation, reduce air leakage

- Distribute public / community buildings evenly around the community within walking distance to encourage travelling by feet

- Urban agriculture, rooftop gardens

- Optimize community circulation

- 3rd Party Certification (i.e. LEED, BOMA BEST, etc.) 
Generally speaking, majority of the strategies / technologies have a very similar rating for both practicality and effectiveness. The only strategy worth nothing is geothermal, where professionals believe is the least practical (due to the high costs for installation), and the benefits towards low-carbon development does not outweigh the cost. The ranking of the strategies from most (effective and practical) to least can be found in Table 6.

\section{Table 6: Ranking the Practicality and Effectiveness of Design Strategies / Technologies from} Most to Least

Particular of design strategies or technologies for low-carbon Practicality Effectiveness building development

\begin{tabular}{|c|c|c|}
\hline Designing the building shape to maximize natural ventilation & 12 & 13 \\
\hline $\begin{array}{l}\text { Building Envelope - increase building insulation, reduce air } \\
\text { leakage }\end{array}$ & 2 & 1 \\
\hline Storm Water Management Strategies (on a building scale) & 7 & 6 \\
\hline Storm Water Management Strategies (on a campus scale) & 8 & 8 \\
\hline Dimmable lighting, maximizing daylight & 4 & 5 \\
\hline Energy efficient lighting design (Indoors and outdoors) & 1 & 2 \\
\hline Shading devices to control solar heat gain & 6 & 7 \\
\hline $\begin{array}{l}\text { Select a reasonable construction equipment system and } \\
\text { optimize its design, selection of energy efficient equipment }\end{array}$ & 14 & 11 \\
\hline Building Automation System & 3 & 3 \\
\hline $\begin{array}{l}\text { Increase vegetation / plant drought resistant or native } \\
\text { species }\end{array}$ & 9 & 12 \\
\hline Zoning for HVAC design & 5 & 4 \\
\hline Geothermal & 19 & 19 \\
\hline $\begin{array}{l}\text { Distribute public / community buildings evenly around the } \\
\text { community within walking distance to encourage travelling } \\
\text { by feet }\end{array}$ & 11 & 10 \\
\hline Centralized heating systems with Individual meters & 13 & 9 \\
\hline Solar water heating & 18 & 16 \\
\hline Green roof & 15 & 15 \\
\hline Urban agriculture, rooftop gardens & 16 & 18 \\
\hline Optimize community circulation & 10 & 14 \\
\hline 3rd Party Certification (i.e. LEED, BOMA BEST, etc.) & 17 & 17 \\
\hline
\end{tabular}




\section{Conclusions}

Based on the results and observations presented in the previous section, the following conclusions can be drawn:

- Although low-carbon emission is a target for the Ontario construction industry, design considerations are still highly dependent on the financial aspects and more attention is required for the technical factors.

- The relationship between the quality of environment and carbon emission seems to be fairly clear in the industry. The challenge is balancing the environmental factors along with managing the needs of the people (quality of life and marketability).

- The amount of experience have a low influence on the perceived practicality and effectiveness of a low-carbon design strategies/technologies.

- Generally speaking, majority of the strategies / technologies identified in Table 5 are fairly practical and effective except for geothermal where professionals identify to be the least practical and effective.

- The professionals in the Ontario construction industry have a fairly low level of experience using strategies and technologies known for low-carbon development, and even lower level of skills and knowledge using assisting tools (which may be due to the lack of available tools).

- To ensure successful low-carbon design and development, suitable training programs, tools and technologies should be developed and introduced to the local construction industry. 
Overall, the Ontario construction industry, as reflected by the survey results from the key players, has not fully embraced the concept of low-carbon design and development. The government and professional organizations are enforcing and encouraging low-carbon design, yet there seems to be a gap with the industries knowledge, experience and available tools to achieve these goals.

To further encourage the bridging of this gap, Ontario has recently put forth an Ontario's Climate Change Strategy published in December 13, 2015. Ontario is committed to "support net-zero buildings across the province through updates to Ontario's Building Code, incentive programs, removal of regulatory barriers, and encouraging the transition to lower carbon fuels and to building materials that store carbon." (Ontario, 2015) The education system should also emphasize on a multidisciplinary education focused on sustainable design to attract a new generation of professionals who has expertise in heat transfer, thermal science, materials engineering, and other traditional building sciences. Currently, University of Ryerson offers an interdisciplinary graduate program in Building Science which focuses on "detail design, building performance, human interaction, life cycle analysis, performance assessment, construction processes and forensic investigation of problems". (Ryerson University, 2016) 


\section{Future Work}

The research team continues working towards achieving the goal mentioned previously through the following activities:

(1) Approach a wider range of relevant professionals in Ontario to achieve a better representation of the current construction industry.

(2) Conduct this research again in 1 or 2 years after the Ontario's Climate Change Strategy published in December 13, 2015 has time to take effect in the industry.

(3) Conduct a study on the available tools and training in Ontario and identify areas requiring additional support

(4) This study completes the first stage of the overall research study identified in the Introduction. Future work includes the following:

a. Survey behavior of occupants of typical residential and commercial communities.

b. Assess the indoor, outdoor environment in selected residential and commercial communities.

c. Audit energy performance of typical residential and commercial units.

d. Study selected residential and commercial communities by simulation.

e. Employ the research outcome in practice.

(5) Conduct similar studies in different provinces, including Alberta, British Columbia, and Quebec to better understand the situation crossing Canada.

(6) This research originated from a study conducted in Heifei, China. Similar studies are being conducted in Beijing, Shanghai, Yichang, Guangzhou, Xi'an. Ongoing comparative 
studies will be conducted to help the team understand the discrepancy between China, as a developing country, and Canada, as a developed country. 


\section{References}

P. T. Doran \& M. K.Zimmerman. (2009). Examining the Scientific Consensus on Climate Change. Eos Transactions American Geophysical Union, Vol. 90 Issue 3.

Architecture 2030. (2015). 2030 Challenges. Retrieved December 31, 2015, from Architecture 2030 : http://architecture2030.org/

Boden, T., Marland, G., \& Andres, R. (2015). Global, Regional, and National Fossil-Fuel CO2 Emissions. Tenn., U.S.A: Carbon Dioxide Information Analysis Center, Oak Ridge National Laboratory.

Brampton. (2015). Development Design Guidelines. Retrieved December 31, 2015, from http://www.brampton.ca/EN/Business/planning-development/guidelinesmanuals/Pages/development-design-guidelines.aspx

City of Windsor. (2015). Sustainable Construction Indicator. Retrieved December 31, 2015, from The City of Windsor: http://www.citywindsor.ca/residents/environment/Environmental-MasterPlan/Goal-B-Create-Healthy-Communities/Pages/Sustainable-Construction-Indicator.aspx

Cook, J., Nuccitelli, D., Green, S. A., Richardson, M., Winkler, B., Painting, R., .. Skuce, A. (June 2013). Quantifying the consensus on anthropogenic global warming in the scientific literature. Environmental Research Letters, Vol. 8 No. 2.

CRC Construction Innovation. (2006). Report: Building Procurement Methods. Brisbane, Australia: Leaders in Construction and Property Research.

Environment Canada. (2014). Sustainable Development. Retrieved December 31, 2015, from Environment Canada: http://www.ec.gc.ca/dd-sd/

EPA. (2015). Causes of Climate Change. Retrieved December 31, 2015, from Climate Change: http://www3.epa.gov/climatechange/science/causes.html

Government of Canada. (2015). Canada's Priorities for COP 21. Retrieved December 31, 2015, from http://www.climatechange.gc.ca/default.asp?Lang=En\&xml=EF6CE373-41AA-4EFA-A97B1EDFB25E6C83

Government of Canada. (2015). Canada's Way Forward on Climate Change. Retrieved December 31, 2015, from Canada's Action on Climate Change: http://www.climatechange.gc.ca/default.asp?lang=En\&n=72F16A84-1

Government of Canada. (2015). Climate Change. Retrieved December 30, 2015, from Environment and Climate Change Canada: http://www.ec.gc.ca/cc/

Government of Canada. (2015). Greenhouse Gas Emissions by Economic Sector. Retrieved December 30, 2015, from Environment and Climate Change Canada: http://www.ec.gc.ca/indicateursindicators/default.asp?lang=en \&n=F60DB708-1

Government of Canada. (2015). The integrated design process. Retrieved from Natural Resources Canada: http://www.nrcan.gc.ca/energy/efficiency/buildings/eenb/integrated-designprocess $/ 4047$ 
Green Building Education Services. (2015). LEED Green Associate Exam Preparation Study Guide (LEED V4 Edition). Lewisville, Texus, United States.

IPCC. (2007). Climate Change 2007: Impacts, Adaptation and Vulnerability. Contribution of Working Group II to the Fourth Assessment Report of the Intergovernmental Panel on Climate Change. Cambridge, UK: Cambridge University Press.

IPCC. (2014). Climate Change 2014: Mitigation of Climate Change. Cambridge, United Kingdom and New York, NY, USA: Cambridge University Press.

Liao, Z. (2013). Personal Communication. (C. Chow, Interviewer)

Markham. (2014). Green Building. Retrieved December 31, 2015, from The Official Site of the City of Markham:

https://www.markham.ca/wps/portal/Markham/BusinessDevelopment/BuildingPermits/Inform ation/GreenBuilding/

Mississauga. (2015). Green Development Strategy is Moving Forward. Retrieved December 31, 2015, from http://www.mississauga.ca/portal/home\%3Bjsessionid=LPYT4X03XNRLBTRPH3XUAQWOF25W2 PW0?paf_gear_id=9700018\&itemld=107700335n

N Oreskes. (2004). Beyond the Ivory Tower: The Scientific Consensus on Climate Change. Science, Vol. 306 no. 5702, p. 1686.

NASA. (2015). A Blanket Around the Earth. Retrieved December 31, 2015, from The consequences of climate change: http://climate.nasa.gov/causes/

NASA. (2015). Carbon Dioxide. Retrieved December 30, 2015, from Global Climate Change - Vital Signs of the Planet: http://climate.nasa.gov/vital-signs/carbon-dioxide/

NASA. (2015). Global Temperature. Retrieved December 30, 2015, from Global Climate Change - Vital Signs of the Planet: http://climate.nasa.gov/vital-signs/global-temperature/

NASA. (2015). Scientific Consensus: Earth's Climate is Warming. Retrieved December 30, 2015, from Global Climate Change - Vital Signs of the Planet: http://climate.nasa.gov/scientific-consensus/

NASA. (2015). The consequences of climate change. Retrieved December 30, 2015, from Global Climate Change - Vital Signs of the Planet: http://climate.nasa.gov/effects/

NASA: Global Climate Change - Vital Signs of the Planet. (n.d.). Global Temperature. Retrieved 12 30, 2015, from http://climate.nasa.gov/vital-signs/global-temperature/

NOAA (National Oceanic and Atmospheric Administration). (n.d.). Retrieved from Warmer Air and Sea, Declining Ice Continue to Trigger Arctic Change.

Ochsendorf, J. (2012). Challenges and Opportunities for Low-Carbon Buildings. Spring Issue of The Bridge on Frontiers of Engineering.

Ontario. (2015). Climate Change Strategy. Retrieved December 30, 2015, from Environment and Climate Change Canada: http://www.ec.gc.ca/cc/ 
OPR (Office of Planning and Research). (2011). List of Worldwide Scientific Organizations. Retrieved December 30, 2015, from Scientific Organizations That Hold the Position That Climate Change Has Been Caused by Human Action: https://www.opr.ca.gov/s_listoforganizations.php

Oreskes, N. (2004). The Scientific Consensus on Climate Change. Science, Vol. 306 no. 5702 p 1686.

Ottawa. (2011). Green Building Policty for the Construction of Corporate Buildings - Corporate Policy. Retrieved December 31, 2015, from http://ottawa.ca/en/city-hall/your-citygovernment/policies-and-administrative-structure/green-building-policy\#P26_2425

Pacala, S., \& Socolow, R. (2004). Stabilization wedges: solving the climate problem for the next 50 years with current technologies. Science 305(5686), 968-972.

Region of Waterloo. (2010). Green Building. Retrieved December 31, 2015, from Region of Waterloo: http://www.regionofwaterloo.ca/en/aboutTheEnvironment/greenbuilding.asp

Ryerson University. (2016). Graduate Program in Building Science. Retrieved 12 31, 2015, from http://www.ryerson.ca/graduate/buildingscience/

Statistics Canda. (2015). Estimates of Population, Canada, Provinces and Territories. Canada.

The City of Hamilton. (2013). Going Green. Retrieved December 31, 2015, from Hamilton Economic Development Office: http://www.investinhamilton.ca/incentives/going-green/

Toronto. (2015). Toronto Green Standard. Retrieved December 31, 2015, from Developing Toronto: http://www1.toronto.ca/wps/portal/contentonly?vgnextoid=f85552cc66061410VgnVCM10000 071d60f89RCRD

United Nations. (1987). Report of the World Commission on Environment and Development: our Common Future. United Nations: NGO Committee on Education.

United Nations Framework Convention on Climate Change (UNFCCC). (2015). UN Climate Change. Retrieved December 30, 2015, from http://newsroom.unfccc.int/

United States Global Change Research Program. (2009). Global Climate Change Impacts in the United States. United States: Cambridge University Press.

University of East Anglia. (n.d.). Climatic Research Unit. Retrieved http://www.cru.uea.ac.uk/ 30, 2015, from http://www.cru.uea.ac.uk/

Vaughan. (2015). Green Buildings. Retrieved December 31, 2015, from Welcome to the City of Vaughan Official Website: https://www.vaughan.ca/cityhall/environmental_sustainability/Pages/GreenBuildings.aspx

W. R. L. Anderegg. (2010). Expert Credibility in Climate Change. Proceedings of the National Academy of Sciences, Vol. 107 No. 27, 12107-12109. 
Appendix:
A. Online Ethics Submission and Review System Approval
B. Online Ethics Submission and Review System Approval Renewal
C. Copy of Questionnaire 


\section{RYERSONUNIVERSITY}

\section{RESEARCH ETHICS BOARD}

To: Christine Wing-Hay Chow

Faculty of Architectural Science - Building Science

Re: REB 2013-321: Understanding the Ontario Construction Industry's Response Towards Green Initiatives Questionnaire

Date: January 27, 2014

Dear Christine Wing-Hay Chow,

The review of your protocol REB File REB 2013-321 is now complete. The project has been approved for a one year period. Please note that before proceeding with your project, compliance with other required University approvals/certifications, institutional requirements, or governmental authorizations may be required.

This approval may be extended after one year upon request. Please be advised that if the project is not renewed, approval will expire and no more research involving humans may take place. If this is a funded project, access to research funds may also be affected.

Please note that REB approval policies require that you adhere strictly to the protocol as last reviewed by the REB and that any modifications must be approved by the Board before they can be implemented. Adverse or unexpected events must be reported to the REB as soon as possible with an indication from the Principal Investigator as to how, in the view of the Principal Investigator, these events affect the continuation of the protocol.

Finally, if research subjects are in the care of a health facility, at a school, or other institution or community organization, it is the responsibility of the Principal Investigator to ensure that the ethical guidelines and approvals of those facilities or institutions are obtained and filed with the REB prior to the initiation of any research.

Please quote your REB file number (REB 2013-321) on future correspondence.

Congratulations and best of luck in conducting your research.

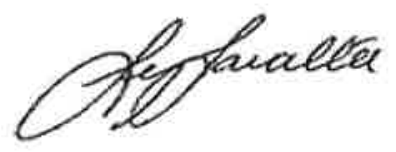

Lynn Lavallée, Ph.D.

Chair, Research Ethics Board 


\section{RYERSONUNIVERSITY}

\section{RESEARCH ETHICS BOARD}

To: Christine Wing-Hay Chow

Faculty of Architectural Science - Building Science

Re: REB 2013-321: Understanding the Ontario Construction Industry's Response Towards Green Initiatives Questionnaire

Date: January 13, 2015

Dear Christine Wing-Hay Chow,

The review of your protocol REB File REB 2013-321 is now complete. This is a renewal for REB File. The project has been approved for a one year period. Please note that before proceeding with your project, compliance with other required University approvals/certifications, institutional requirements, or governmental authorizations may be required.

This approval may be extended after one year upon request. Please be advised that if the project is not renewed, approval will expire and no more research involving humans may take place. If this is a funded project, access to research funds may also be affected.

Please note that REB approval policies require that you adhere strictly to the protocol as last reviewed by the REB and that any modifications must be approved by the Board before they can be implemented. Adverse or unexpected events must be reported to the REB as soon as possible with an indication from the Principal Investigator as to how, in the view of the Principal Investigator, these events affect the continuation of the protocol.

Finally, if research subjects are in the care of a health facility, at a school, or other institution or community organization, it is the responsibility of the Principal Investigator to ensure that the ethical guidelines and approvals of those facilities or institutions are obtained and filed with the REB prior to the initiation of any research.

Please quote your REB file number (REB 2013-321) on future correspondence.

Congratulations and best of luck in conducting your research.

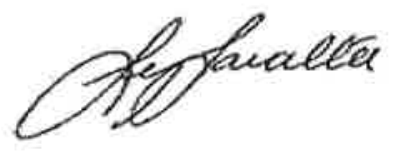

Lynn Lavallée, Ph.D.

Chair, Research Ethics Board 


\section{Low-Carbon Initiatives for the Construction Industry Questionnaire}

1. General Information :

a) Your occupation (circle all that applies):

\begin{tabular}{|l|l|l|l|l|l|l|}
\hline Architect & Engineer & Developer & Government & Sales & Contractor & $\begin{array}{l}\text { Facility } \\
\text { Manger }\end{array}$ \\
\hline & & & & & \\
\hline & & & & & \\
\hline
\end{tabular}

b) How many years have you worked in this position:

c) How many projects have you participated in during this position:

d) If you are willing to accept a one-time follow-up telephone survey, please provide your contact information:

e) If you wish to receive a copy of the final

Name:

Telephone:

\section{Email:} report, please provide your email:

2. Rating from 1 to 5 ( $1=$ least influential and $5=$ most influential), rate how the influencing factors affect the planning and design of the latest construction project that you have worked on. In addition, rate how you believe these factors should influence the planning and design of a low-carbon building.

\begin{tabular}{|l|}
\hline Factors \\
\hline Architect's Design Concept \\
\hline Client's Project Scope \\
\hline Site Characteristics \\
\hline Weather Conditions \\
\hline User-Group Preferences \\
\hline Public Transportation \\
\hline Project Budget \\
\hline Project Goals (I.e. Energy Efficiency, Green \\
\hline Attributes etc.) \\
\hline Site Selection \\
\hline Available Resources (i.e. Materials) \\
\hline Construction Techniques / Methodology \\
\hline Construction Schedule \\
\hline Sales / Rental Price \\
\hline Waste Treatment \\
\hline Government Incentives \\
\hline
\end{tabular}

\begin{tabular}{l|l} 
The importance in your latest project & In your opinion, the importance to \\
achieve low-carbon goals
\end{tabular}

3. Within a range of 1 to $5(1=$ least influential and $5=$ most influential), rate the impact of the basic components/attributes of a typical community on the marketability, carbon emission, environment and quality of life.

\begin{tabular}{|c|c|c|c|c|c|}
\hline \multicolumn{2}{|l|}{ Factors } & Marketability & Carbon Emission & Environment & Quality of Life \\
\hline \multirow[t]{4}{*}{ Building: } & Aesthetics & & & & \\
\hline & Building Envelope & & & & \\
\hline & Mechanical Systems & & & & \\
\hline & Building Quality & & & & \\
\hline \multicolumn{6}{|c|}{ Floor Area Ratio } \\
\hline \multicolumn{6}{|c|}{ Building Density } \\
\hline \multicolumn{6}{|c|}{ Green space / landscape } \\
\hline \multicolumn{6}{|l|}{ Parking } \\
\hline \multicolumn{6}{|c|}{ Transportation } \\
\hline \multicolumn{6}{|c|}{ Entertainment } \\
\hline \multicolumn{6}{|l|}{ Security } \\
\hline \multicolumn{6}{|c|}{ Childcare / School } \\
\hline \multicolumn{6}{|c|}{ Commercial Buildings (i.e. retail, offices etc.) } \\
\hline Communi & Center & & & & \\
\hline
\end{tabular}


4. Within a range of 1 to 5 , rate the feasibility ( $1=$ least feasible, $5=$ most feasible), effectiveness $(1=$ least effect, $5=$ most effective), personal experience ( $1=$ no experience, $5=$ very experienced), and available tools $(1=$ not available, $5=$ very sufficient $)$ of design strategies or technologies for low-carbon construction.

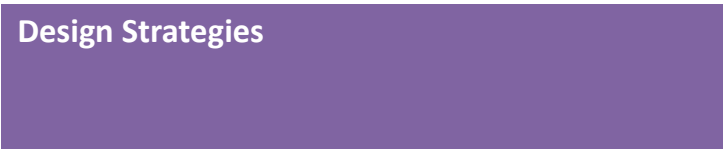

Design the building shape to maximize natural ventilation

Building Envelope - increase building insulation, reduce air leakage

\section{Storm Water Management Strategies (Buildings)}

Storm Water Management Strategies

(Community)

Dimmable lighting, maximizing daylight

Energy efficient lighting design (Indoors and outdoors)

\section{Shading devices to control solar heat gain}

Select a reasonable construction equipment system and optimize its design, selection of

energy efficient equipment

\section{Building Automation System}

Increase vegetation / plant drought resistant or native species

\section{Zoning for HVAC design}

Geothermal

Distribute public / community buildings evenly around the community within walking distance to encourage travelling by feet

Centralized heating systems with Individual

meters

Solar water heating

Green roof

Urban agriculture, rooftop gardens

Optimize community circulation

5. For projects you've previously completed,

\begin{tabular}{|c|c|c|c|}
\hline$i$ & Have you returned to the project? & Never & Some \\
\hline ii. & Do you evaluate / rate them? & Never & Some \\
\hline
\end{tabular}

iii. Have you learned from your past projects and implement changes to future projects? Yes No

iv. Have you worked on a project that participated in a third-party certification program (i.e. LEED, BOMA BESt, Living Building Challenge etc.)? Yes No

Thank you for your participation.

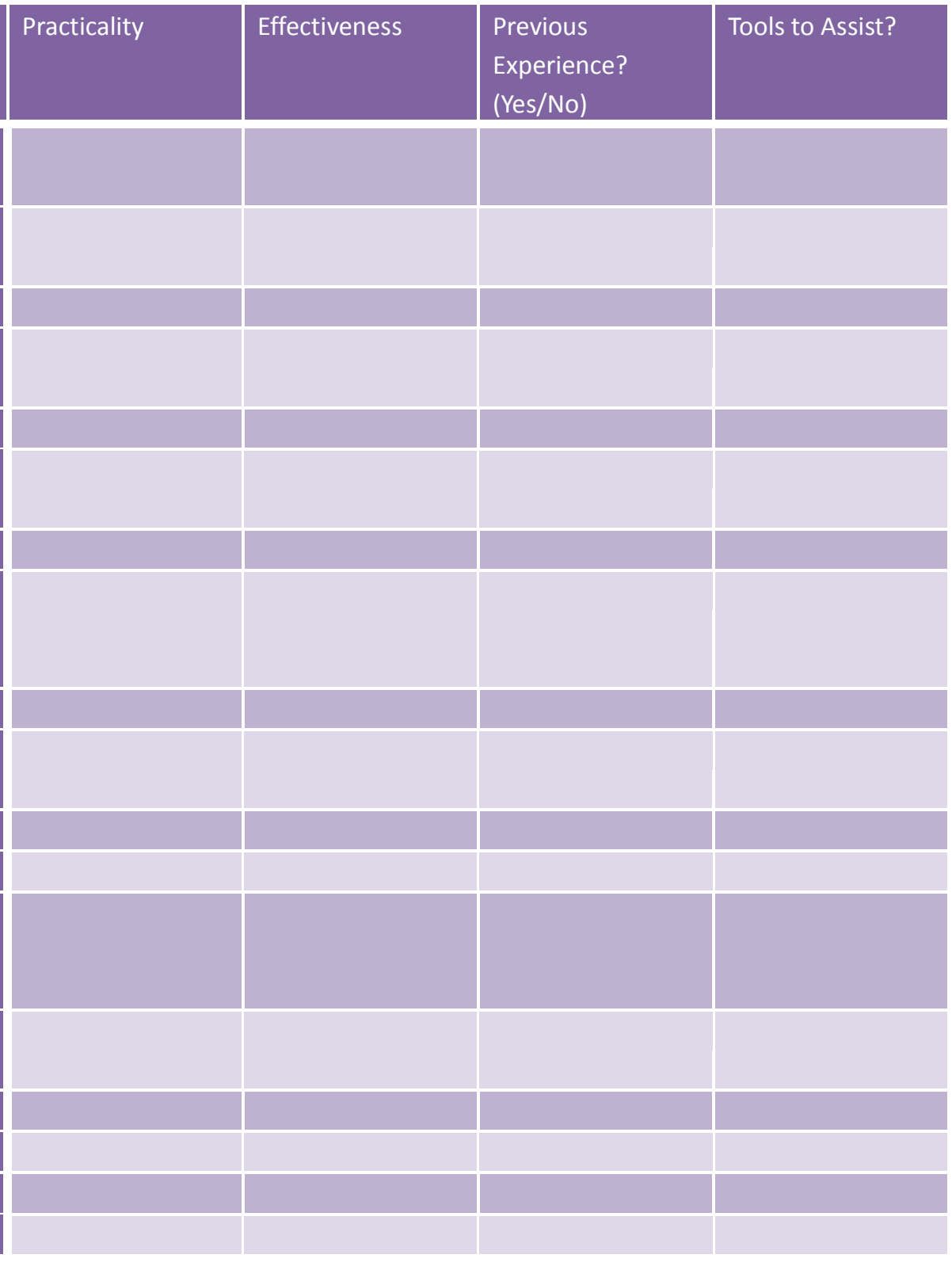

